\title{
A 343 aggregates exhibit enhanced prion-like seeding activity in mice
}

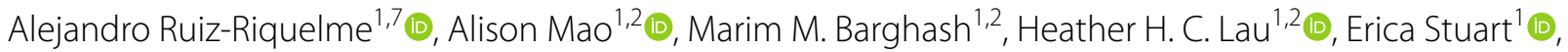

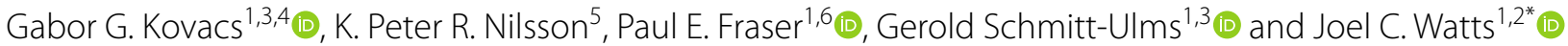

\begin{abstract}
When injected into genetically modified mice, aggregates of the amyloid- $\beta$ (A $\beta$ ) peptide from the brains of Alzheimer's disease (AD) patients or transgenic AD mouse models seed cerebral A $\beta$ deposition in a prion-like fashion. Within the brain, $A \beta$ exists as a pool of distinct $C$-terminal variants with lengths ranging from 37 to 43 amino acids, yet the relative contribution of individual $C$-terminal $A \beta$ variants to the seeding behavior of $A \beta$ aggregates remains unknown. Here, we have investigated the relative seeding activities of $A \beta$ aggregates composed exclusively of recombinant $A \beta 38, A \beta 40, A \beta 42$, or $A \beta 43$. Cerebral $A \beta 42$ levels were not increased in $A p p^{N L-F}$ knock-in mice injected with $A \beta 38$ or $A \beta 40$ aggregates and were only increased in a subset of mice injected with $A \beta 42$ aggregates. In contrast, significant accumulation of $A \beta 42$ was observed in the brains of all mice inoculated with $A \beta 43$ aggregates, and the extent of $A \beta 42$ induction was comparable to that in mice injected with brain-derived $A \beta$ seeds. Mice inoculated with $A \beta 43$ aggregates exhibited a distinct pattern of cerebral $A \beta$ pathology compared to mice injected with brain-derived $A \beta$ aggregates, suggesting that recombinant $A \beta 43$ may polymerize into a unique strain. Our results indicate that aggregates containing longer $A \beta C$-terminal variants are more potent inducers of cerebral $A \beta$ deposition and highlight the potential role of $A \beta 43$ seeds as a crucial factor in the initial stages of $A \beta$ pathology in $A D$.
\end{abstract}

Keywords: Alzheimer's disease, Prion-like propagation, Amyloid- $\beta$, Knock-in mice, Strains

\section{Introduction}

Alzheimer's disease (AD) is a progressive neurodegenerative disorder of ageing and is the most common cause of dementia in humans. The brains of AD patients contain two hallmark pathologies: extracellular amyloid plaques containing aggregated amyloid- $\beta(A \beta)$ peptide and intracellular neurofibrillary tangles composed of aggregated and hyperphosphorylated tau protein. Some AD cases also feature $A \beta$ deposition within cerebral blood vessels, referred to as $A \beta$ cerebral amyloid angiopathy (CAA). One hypothesis for the molecular sequence of events in $\mathrm{AD}$, the amyloid cascade hypothesis, speculates that the

\footnotetext{
*Correspondence: joel.watts@utoronto.ca

${ }^{1}$ Tanz Centre for Research in Neurodegenerative Diseases, University of Toronto, Krembil Discovery Tower, Rm. 4KD481, 60 Leonard Ave., Toronto, ON M5T 0S8, Canada

Full list of author information is available at the end of the article
}

polymerization and deposition of $A \beta$ peptide is the initiating event in the disease, which stimulates the downstream aggregation and deposition of tau within neurons [80]. The $A \beta$ peptide is produced by cleavage of the amyloid precursor protein (APP) by $\beta$ - and $\gamma$-secretase, and mutations within the genes encoding APP or $\gamma$-secretase components that increase $A \beta$ levels or augment its aggregation potential cause early-onset familial forms of $A D$, arguing that $A \beta$ aggregation is central to $A D$ pathogenesis.

In $\mathrm{AD}$, both $\mathrm{A} \beta$ and tau exhibit hierarchical patterns of deposition within the brain $[6,88]$. A prion-like mechanism in which pre-existing $\mathrm{A} \beta$ "seeds" template the addition of monomeric $A \beta$ to growing $A \beta$ aggregates has been proposed to explain the apparent spreading of $A \beta$ aggregates within the brains of $\mathrm{AD}$ patients [31, 67]. In support of this theory, intracerebral or peripheral inoculation of 
transgenic mice expressing mutant or wild-type human APP with brain extracts rich in $A \beta$ aggregates induces the cerebral deposition of $A \beta$ in a prion-like fashion [19, 32, 55 , 57]. A $\beta$ aggregates purified from the brains of transgenic $\mathrm{AD}$ mouse models or composed exclusively of synthetic $A \beta$ peptides are sufficient to induce $A \beta$ pathology in recipient mice, demonstrating that $A \beta$ aggregates themselves are responsible for the prion-like transmission of $A \beta$ pathology [83, 84]. While $A \beta$ pathology is transmissible in genetically modified mice, primates [71], and potentially in humans exposed to $A \beta$-contaminated growth hormone preparations or dura mater grafts $[3,18$, $21,23,25,30,39,68,72]$, there is currently no evidence that the full clinicopathological spectrum of AD can be transmitted from person-to-person $[2,49]$.

The precise species of $A \beta$ aggregates that mediates their prion-like seeding behavior remains unknown. Within the brain, $A \beta$ aggregates can vary greatly in size, ranging from dimers to oligomers to fibrils. While there is evidence that soluble and/or oligomeric $A \beta$ assemblies exhibit seeding activity in mice [20,33, 43], it is clear that larger, protease-resistant fibrillar $A \beta$ species are also effective at inducing cerebral $\mathrm{A} \beta$ deposition [43, 84]. Furthermore, the $A \beta$ peptide itself is heterogeneous, with variability in the primary amino acid sequence existing at both the $\mathrm{N}$ - and $\mathrm{C}$-terminal ends. $\mathrm{A} \beta$ variants with $\mathrm{C}$-termini that terminate between residues 37 and 43 of the cognate $A \beta$ sequence are generated due to differential cleavage of membrane-embedded APP-derived fragments by presenilin proteins, the catalytic components of the $\gamma$-secretase complex $[4,41,86]$. Longer $A \beta$ peptides such as $A \beta 42$ and $A \beta 43$ are more aggregation-prone and are typically found within the cores of amyloid plaques $[29,76]$, whereas shorter peptides such as $A \beta 38$ and A $\beta 40$ are found deposited within the periphery of densecore plaques and constitute the principal components of A $\beta$ CAA $[17,58,92]$.

An additional level of complexity is that $A \beta$ aggregates can exist as conformationally distinct "strains" [37, 45, 52, $53,63,64,66,69]$, some of which are capable of inducing the formation of morphologically distinct $A \beta$ deposits when injected into mice $[13,15,24,70,83,94]$. Interestingly, $A \beta$ aggregates present in brains from $A D$ patients or transgenic AD mouse models exhibit much higher seeding activity in mice than $A \beta$ aggregates composed of synthetic $A \beta[55,84]$. One potential explanation is that synthetic and brain-derived $A \beta$ aggregates are structurally distinct. Indeed, the structure of CAA-associated A $\beta 40$ aggregates purified from an AD brain is markedly different from those obtained via the polymerization of synthetic $A \beta$ in vitro [38].

We recently demonstrated that intracerebral injection of $A p p^{\mathrm{NL}-\mathrm{F}}$ knock-in mice with brain-derived $\mathrm{A} \beta$ aggregates results in the robust induction of cerebral $\mathrm{A} \beta$ deposition [73]. These mice represent an ideal paradigm for assessing the prion-like seeding behavior of $A \beta$ aggregates since they lack artifacts associated with APP over-expression, and APP is expressed with the correct spatiotemporal pattern within the brain $[74,75]$. In this study, we used $A p p^{\mathrm{NL}-\mathrm{F}}$ mice and recombinant $\mathrm{A} \beta$ species to compare the relative seeding activities of $A \beta$ aggregates composed exclusively of individual $A \beta$ $\mathrm{C}$-terminal peptide variants. Unexpectedly, we found that recombinant $A \beta 43$ aggregates were uniquely able to induce cerebral $A \beta$ deposition with an efficiency comparable to brain-derived $A \beta$ aggregates.

\section{Materials and methods \\ Production of protease-resistant recombinant $A \beta$ aggregates}

Stocks $(0.5 \mathrm{mg})$ of recombinant $\mathrm{A} \beta 1-38, \mathrm{~A} \beta 1-40$, $\mathrm{A} \beta 1$ 42 and $A \beta 1-43$ peptides were purchased from rPeptide (catalog numbers A-1078-1, A-1001-1, A-1002-1, and A-1005-1, respectively). Peptides were dissolved in hexafluoroisopropanol (HFIP), separated into $50 \mu \mathrm{g}$ aliquots, and then HFIP was evaporated overnight. Peptide aliquots were stored at $-80{ }^{\circ} \mathrm{C}$. For production of aggregates, $50 \mu \mathrm{g}$ of dried peptide film was resuspended in 20 $\mu \mathrm{L}$ DMSO, diluted with $480 \mu \mathrm{L} 10 \mathrm{mM}$ sodium phosphate (NaP) buffer ( $\mathrm{pH} 7.4$ ), and then $\mathrm{A} \beta$ was quantified by measuring absorbance at $280 \mathrm{~nm}$ using a Nanodrop ND-1000 spectrophotometer. A $\beta$ samples in $1.5 \mathrm{~mL}$ tubes were diluted to $5 \mu \mathrm{M}$ in NaP buffer and then $800 \mu \mathrm{L}$ aliquots were incubated at $37^{\circ} \mathrm{C}$ for $72 \mathrm{~h}$ in an Eppendorf Thermomixer with continuous shaking at $900 \mathrm{rpm}$. For samples that were used for inoculation of mice, $A \beta$ aggregates were treated with $0.5 \mu \mathrm{M}(14.5 \mu \mathrm{g} / \mathrm{mL})$ proteinase $\mathrm{K}$ (PK) (Thermo Scientific \#EO0491) for $1 \mathrm{~h}$ at $37^{\circ} \mathrm{C}$ with shaking at $600 \mathrm{rpm}$, and then the reaction was halted by the addition of $2 \mathrm{mM}$ PMSF. Samples were centrifuged at $100,000 \times g(48,000 \mathrm{rpm})$ for $1 \mathrm{~h}$ at $4{ }^{\circ} \mathrm{C}$ in a TLA-55 rotor (Beckman), and then the pellets were resuspended in $\mathrm{dH}_{2} \mathrm{O}$ and stored at $-30{ }^{\circ} \mathrm{C}$. The concentration of the PK-resistant recombinant $\mathrm{A} \beta$ aggregates was determined using an $A \beta_{1-x}$ ELISA kit (IBL America \#27729) following treatment with formic acid.

\section{Thioflavin $\mathrm{T}$ aggregation assays}

Recombinant $\mathrm{A} \beta$ samples ( $5 \mu \mathrm{M}$ in NaP buffer) were kept on ice and then $20 \mu \mathrm{M}$ Thioflavin T (ThT; Sigma-Aldrich \#T3516) was added to a final concentration of $20 \mu \mathrm{M}$. Aliquots of $100 \mu \mathrm{L}$ were placed in black 96-well clear bottom plates (Nunc \#265301) and then incubated in a microplate plate reader (BMG CLARIOstar) set at $37^{\circ} \mathrm{C}$. Samples were subjected to rounds of $1 \mathrm{~min}$ rest and $4 \mathrm{~min}$ shaking (double orbital, $700 \mathrm{rpm}$ ), and ThT fluorescence 
(excitation: $444 \pm 5 \mathrm{~nm}$; emission: $485 \pm 5 \mathrm{~nm}$ ) was measured every $5 \mathrm{~min}$.

\section{Conformational stability assays}

A $\beta$ conformational stability assays were performed essentially as previously described [46]. Briefly, aliquots of guanidine hydrochloride $(\mathrm{GdnHCl})$ stocks $(30 \mu \mathrm{L})$ were added to $10 \mu \mathrm{L}$ of $5 \mu \mathrm{M}$ recombinant $\mathrm{A} \beta$ aggregates to give final $\mathrm{GdnHCl}$ concentrations of $1,2,2.5,3,3.5$, 4, $4.5,5,5.5$, or $6 \mathrm{M}$. Samples were incubated at room temperature for $2 \mathrm{~h}$ with shaking $(800 \mathrm{rpm})$ and then diluted to $0.4 \mathrm{M} \mathrm{GdnHCl}$ in PBS containing $0.5 \%(\mathrm{w} / \mathrm{v})$ sodium deoxycholate and $0.5 \%(\mathrm{v} / \mathrm{v}) \mathrm{NP}-40$ to a final volume of $600 \mu \mathrm{L}$. Samples were then treated with $20 \mu \mathrm{g} / \mathrm{mL}$ PK for $1 \mathrm{~h}$ at $37{ }^{\circ} \mathrm{C}$ with shaking (600 rpm). Digestions were stopped by the addition of $2 \mathrm{mM}$ PMSF, and then sarkosyl was added to a final concentration of $2 \%(\mathrm{v} / \mathrm{v})$. Following ultracentrifugation at $100,000 \times g$ for $1 \mathrm{~h}$ at $4{ }^{\circ} \mathrm{C}$ in a TLA- 55 rotor, pellets were resuspended in $100 \mu \mathrm{L}$ of formic acid, vortexed, and then sonicated in a water bath sonicator for $10 \mathrm{~min}$. The formic acid was evaporated using a speed-vac for $30 \mathrm{~min}$, and then dried pellets were resuspended in 1X Bolt LDS loading buffer and boiled for $10 \mathrm{~min}$. Samples were then analyzed by immunoblotting as described below.

\section{PK digestion of recombinant $A \beta$ aggregates}

Aliquots of $5 \mu \mathrm{M}$ recombinant $\mathrm{A} \beta$ aggregates $(5 \mu \mathrm{L})$ were treated with various concentrations of PK in a final volume of $20 \mu \mathrm{L}$ PBS containing $0.5 \%(\mathrm{w} / \mathrm{v}$ ) sodium deoxycholate and $0.5 \%(\mathrm{v} / \mathrm{v})$ NP-40. Digestions were performed for $1 \mathrm{~h}$ at $37^{\circ} \mathrm{C}$ with shaking (600 rpm). Digestions were stopped by the addition of $2 \mathrm{mM}$ PMSF, and then PBS containing $2 \%(\mathrm{v} / \mathrm{v})$ sarkosyl was added to generate a final volume of $200 \mu \mathrm{L}$. Samples were then ultracentrifuged and processed identically as described above for the conformational stability assays.

\section{Dye-binding assays}

Dye-binding assays were performed essentially as described previously [44]. Samples containing $5 \mu \mathrm{M}$ A $\beta$ aggregates were prepared as indicated above. Dyes were added to the samples at a concentration of $5 \mu \mathrm{M}$ for curcumin (Sigma-Aldrich \#C1386) or $4 \mu \mathrm{M}$ for hFTAA, and then samples were incubated for $15 \mathrm{~min}$ at room temperature with shaking $(850 \mathrm{rpm})$. To remove unbound dye, samples were placed in Slide-A-Lyzer Mini dialysis devices with a molecular weight cutoff of $10 \mathrm{kDa}$ (Thermo Scientific \#69570) and dialysed against $\mathrm{dH}_{2} \mathrm{O}$ for $\sim 50 \mathrm{~min}$. After dialysis samples were recovered and placed in a half-area black clear-bottom 96-well microplate (Greiner Bio-One \#675096). Fluorescence emission spectra were measured using a BMG CLARIOstar microplate reader. For curcumin, an excitation bandwidth of $432 \pm 7.5 \mathrm{~nm}$ was used and fluorescence emission values from $460 \pm 5$ to $625 \pm 5 \mathrm{~nm}$ were measured. For hFTAA, an excitation bandwidth of $488 \pm 5 \mathrm{~nm}$ was used and fluorescence values from $513 \pm 5$ to $690 \pm 5 \mathrm{~nm}$ were measured. Background signal from reactions containing only dye were subtracted, and then fluorescence signals were normalized to the highest value obtained, which was set at 1.0.

\section{Purification of brain-derived $A \beta$ aggregates}

PK-resistant $A \beta$ aggregates were purified from the brain of an 8-month-old female TgCRND8 mouse [11] as previously described [73]. As a negative control, a brain from an 11-month-old male non-transgenic TgCRND8 littermate was subjected to the same purification protocol. For purification of $A \beta$ aggregates from $A p p^{\mathrm{NL}-\mathrm{F}}$ mice, brains from two 20-month-old female mice were used. The concentration of the purified $A \beta$ aggregates was determined using an $A \beta_{1-x}$ ELISA kit (IBL America \#27729) following treatment with formic acid.

\section{Electron microscopy}

Samples were sonicated in a water bath sonicator for 10 min prior to analysis. Negative-stain electron microscopy was performed as follows: $9 \mu \mathrm{L}$ of purified brainderived or recombinant PK-resistant $A \beta$ aggregates were placed on a formvar/copper grid and then incubated for $2 \mathrm{~min}$. Excess sample was removed using filter paper, and then $9 \mu \mathrm{L}$ of $1 \%(\mathrm{w} / \mathrm{v})$ phosphotungstic acid was added to the grid and incubated for $2 \mathrm{~min}$. Excess phosphotungstic acid was removed and the grid was stored in the dark at room temperature until examined using either a Hitachi H7000 or a Talos L120C transmission electron microscope.

\section{Mice}

Homozygous $A p p^{\mathrm{NL}-\mathrm{F}}$ knock-in mice on a $\mathrm{C} 57 \mathrm{Bl} / 6$ background [74], which express murine APP containing the Swedish (KM670/671NL) and Iberian/Beyreuther (I716F) mutations as well as a humanized $A \beta$ region, were maintained on a $12 \mathrm{~h}$ light/12 h dark cycle and were given unlimited access to food and water. All studies utilized roughly equal numbers of male and female animals. All mouse experiments were performed in accordance with guidelines set by the Canadian Council on Animal Care under a protocol (AUP \#4263.11) approved by the University Health Network Animal Care Committee.

\section{Intracerebral inoculations}

Prior to inoculation, the purified or recombinant $A \beta$ aggregates were diluted to a concentration of $33.3 \mathrm{ng} / \mu \mathrm{L}$, sonicated for $10 \mathrm{~min}$ using a water bath sonicator, and 
then diluted 1:10 using inoculum diluent buffer $[5 \%(\mathrm{w} / \mathrm{v})$ BSA prepared in sterile PBS]. 6-week-old $A p p^{\mathrm{NL}-\mathrm{F}}$ mice were anaesthetized using isoflurane gas and then freehand inoculated into the right parietal lobe at a depth of $3 \mathrm{~mm}$ with $30 \mu \mathrm{L}$ of sample using a BD SafetyGlide $1 \mathrm{~mL}$ tuberculin syringe containing a 27 -gauge $1 / 2^{\prime \prime}$ needle (BD $\# 305945)$. Each mouse received $100 \mathrm{ng}$ of either purified or recombinant $A \beta$ aggregates. As a negative control, $\mathrm{dH}_{2} \mathrm{O}$ diluted 1:10 (vol/vol) in inoculum diluent buffer was used. The individual performing the injections was not blinded to the identity of the inoculum. Inoculated mice were monitored daily for routine health. Mice were euthanized at 6 months post-inoculation (180-183 days post-inoculation) by transcardiac perfusion with $0.9 \%$ saline solution while under sodium pentobarbital anaesthesia $(50 \mathrm{mg} / \mathrm{kg}$ ). Brains were then removed from the skull and bisected parasagittally. The right half of the brain was fixed in 10\% neutral buffered formalin and used for neuropathological analysis whereas the left half was frozen and stored at $-80^{\circ} \mathrm{C}$ for biochemical studies.

\section{ELISAs}

For determining total levels of $A \beta 42$ in brain homogenates from inoculated mice, frozen hemibrains were homogenized to $10 \%(\mathrm{w} / \mathrm{v})$ in sterile PBS using a Precellys MiniLys homogenizer and CK14 soft tissue homogenization kits (Bertin). Protein concentration was determined using the BCA assay (Thermo Scientific) and then $500 \mu \mathrm{g}$ of total protein was brought up to a volume of 100 $\mu \mathrm{L}$ using PBS. Chilled $95 \%$ formic acid $(200 \mu \mathrm{L}$; SigmaAldrich \#F0507) was added to each sample, which were then sonicated in a water bath sonicator for $5 \mathrm{~min}$. Samples were ultracentrifuged at $100,000 \times g$ in a TLA- 55 rotor for $1 \mathrm{~h}$ at $4{ }^{\circ} \mathrm{C}$, and then the resulting supernatants were dried using a speed-vac. The dried proteins were resuspended in $50-100 \mu \mathrm{L}$ of PBS, sonicated for $10 \mathrm{~min}$ using a Qsonica Q700 sonicator coupled to a microplate horn (\#431MPX) set at 70\% amplitude, and then stored at $-80{ }^{\circ} \mathrm{C}$. For analysis of PK-resistant A $\beta 42$ levels, $500 \mu \mathrm{g}$ of brain homogenate was digested with a final concentration of $100 \mu \mathrm{g} / \mathrm{mL}$ PK for $1 \mathrm{~h}$ at $37^{\circ} \mathrm{C}$ with shaking in a volume of $100 \mu \mathrm{L}$ (diluted with PBS; final PK:protein ratio of 1:50). The digestions were halted by addition of $2 \mathrm{mM}$ PMSF, and then samples were treated with formic acid and processed identically to the undigested samples. For analysis of soluble A $\beta 42$ levels, brain homogenates were treated with an equal volume of $0.4 \%(\mathrm{v} / \mathrm{v})$ diethylamine $/ 100 \mathrm{mM} \mathrm{NaCl}$, ultracentrifuged at $100,000 \times g$ for $1 \mathrm{~h}$ at $4{ }^{\circ} \mathrm{C}$, and then neutralized by the addition of 0.1 volumes of $0.5 \mathrm{M}$ Tris- $\mathrm{HCl} \mathrm{pH} \mathrm{6.8.} \mathrm{Total,} \mathrm{PK-resist-}$ ant, and soluble $A \beta 42$ levels were measured using $A \beta_{x-42}$ ELISA kits (ThermoFisher Scientific \#KHB3441) whereas levels of $A \beta$ species containing an intact $\mathrm{N}$-terminus were determined using an $A \beta_{1-\mathrm{x}}$ ELISA kit (IBL America \#27729). Samples that fell below the lower detection limit for the $A \beta_{1-x}$ ELISA and the soluble $A \beta_{x-42}$ ELISA were not included in the analysis.

\section{Immunoblotting and silver staining}

Nine volumes of $10 \%(\mathrm{w} / \mathrm{v})$ brain homogenate were mixed with one volume of 10X detergent buffer [5\% $(\mathrm{v} / \mathrm{v})$ NP-40, 5\% (w/v) sodium deoxycholate in PBS] and then incubated on ice for $20 \mathrm{~min}$. Samples were clarified by centrifugation at $1000 \times g$ for $5 \mathrm{~min}$ at $4{ }^{\circ} \mathrm{C}$ to generate detergent-extracted brain homogenate. For analysis of insoluble $A \beta, 0.5-1 \mathrm{mg}$ of detergent-extracted brain homogenate was treated with a final concentration of $50 \mu \mathrm{g} / \mathrm{mL}$ PK in a volume of $100 \mu \mathrm{L}$ for a final PK:protein ratio of 1:50. Digestions were performed for $1 \mathrm{~h}$ at $37^{\circ} \mathrm{C}$ with shaking, and then reactions were halted by addition of PMSF to a final concentration of $2 \mathrm{mM}$. After the addition of sarkosyl to a final concentration of $2 \%$ (vol/ $\mathrm{vol}$ ), samples were ultracentrifuged at 48,000 rpm for $1 \mathrm{~h}$ at $4{ }^{\circ} \mathrm{C}$ using a TLA-55 rotor (Beckman Coulter). Pellets were resuspended in $1 \mathrm{X}$ Bolt LDS sample buffer containing $2.5 \%(\mathrm{vol} / \mathrm{vol}) \beta$-mercaptoethanol, boiled, and then analyzed by immunoblotting. Samples were analyzed by SDS-PAGE using Bolt 4-12\% Bis-Tris Plus gels (Thermo Scientific). For separation of individual $A \beta$ variants, selfpoured Bicine/Tris 10\% polyacrylamide gels containing $8 \mathrm{M}$ urea were used [82]. For silver staining, the Thermo Scientific Pierce Silver Stain Kit (catalog \#PI24612) was used. For immunoblotting, proteins were transferred onto $0.45 \mu \mathrm{m}$ Immobilon-P PVDF membranes and then membranes were blocked with $5 \%(\mathrm{w} / \mathrm{v})$ non-fat skim milk in TBS containing $0.05 \%(\mathrm{v} / \mathrm{v})$ Tween-20 (TBST). For the analysis of recombinant $A \beta$ by immunoblotting, blots were boiled in PBS using a microwave prior to blocking. Membranes were incubated with anti-A $\beta$ 6E10 antibody (BioLegend \#803001; 1:4000 dilution) or anti-A $\beta$ (N-terminal) antibody 82E1 (IBL America \#10323; 1:2,000 dilution) diluted in blocking buffer overnight at $4{ }^{\circ} \mathrm{C}$, and then blots were washed 3 times with TBST. Blots were then incubated with horseradish peroxidase-conjugated secondary antibodies (Bio-Rad) at room temperature followed by 3 washes with TBST. Blots were treated with Western Lightning ECL Pro (PerkinElmer) or SuperSignal West Dura ECL (Thermo Scientific) and then exposed to HyBlot CL film.

\section{Neuropathology}

Formalin-fixed brains were embedded in paraffin and then processed for immunohistochemistry as previously described [44] using sagittal sections $(5 \mu \mathrm{m})$ taken at the midline of the brain $(\sim 0.5-1 \mathrm{~mm}$ lateral) mounted onto glass slides. Sections were pre-treated with $88 \%$ 
formic acid for 6 min to facilitate detection of $A \beta$ and then blocked using the M.O.M kit (Vector Laboratories). Immunostaining was performed using the following antibodies: anti-A 342 12F4 (BioLegend \#805501; 1:2,000 dilution) or anti-A $\beta$ (N-terminus) 82E1 (IBL America \#10323; 1:1000 dilution). Sections were processed using the ImmPress HRP detection kit (Vector Laboratories), developed using 3,3'-diaminobenzidine (DAB), and counterstained with haematoxylin. Slides were either analyzed using a Leica DM6000B microscope and photographed using $20 \times$ or $40 \times$ objectives, or were scanned using the TissueScope LE120 slide scanner in conjunction with the TissueSnap preview station (Huron Digital Pathology). For semi-quantitative analysis of $A \beta 42$ pathology in the brains of inoculated $A p p^{\mathrm{NL}-\mathrm{F}}$ mice, the extent of pathology was scored across 4 different brain regions (occipital cortex, olfactory bulb, subcallosal region, and cerebellum) within a single section using the following system: 0 , no $A \beta$ deposition; 1 , mild $A \beta$ deposition; 2, moderate $A \beta$ deposition; 3 , intense $A \beta$ deposition. $A \beta$ CAA was assessed by counting the number of $A \beta 42$-positive meningeal blood vessels overlying the frontal to occipital cortex. Spontaneous $A \beta$ deposition was assessed by counting the number of $A \beta$ plaques in the frontal/parietal cortex.

\section{Statistical analysis}

All statistical analysis was performed using GraphPad Prism software (version 9.0.0) with a significance threshold of $P=0.05$. For comparisons between groups of inoculated mice, Gaussian distributions were not assumed and therefore the Kruskal-Wallis test followed by Dunn's multiple comparisons test was used. For in vitro samples, a standard one-way ANOVA followed by Tukey's multiple comparisons test was used. For comparison between total and PK-resistant A $\beta$ levels in A $\beta 43$-inoculated mice, a paired, two-tailed $t$-test was used.

\section{Results}

\section{Generation of recombinant $A \beta$ aggregates for in vivo seeding studies}

The four most common full-length $A \beta$ peptide variants are $A \beta 1-38, A \beta 1-40, A \beta 1-42$, and $A \beta 1-43$, which, for simplicity, will be referred to as $A \beta 38, A \beta 40, A \beta 42$, and $\mathrm{A} \beta 43$, respectively. These peptides differ from each other at their C-termini, with the longer variants incorporating additional residues from the APP transmembrane domain (Fig. 1a). To characterize the relative seeding capacity of individual $A \beta C$-terminal variants, we generated $A \beta$ aggregates by polymerizing recombinant $A \beta$ peptides in sodium phosphate buffer by continuous shaking at $37^{\circ} \mathrm{C}$. This buffer was chosen because it has previously led to the formation of proteinase $\mathrm{K}$ (PK)resistant synthetic $A \beta$ aggregates that exhibited seeding activity when injected into transgenic mice [83]. In a realtime Thioflavin $\mathrm{T}$ (ThT) fluorescence aggregation assay, all four $A \beta$ peptides formed aggregates within $12 \mathrm{~h}$ as revealed by an increase in ThT fluorescence (Fig. 1b). As expected, a fraction of the polymerized $A \beta$ preparations were resistant to PK digestion (Fig. 1c).

For inoculation studies, recombinant $\mathrm{A} \beta$ aggregates were generated by shaking at $37^{\circ} \mathrm{C}$ for three days followed by $\mathrm{PK}$ digestion and then ultracentrifugation to isolate insoluble, PK-resistant $A \beta$ aggregates (Fig. 1d). When imaged by electron microscopy, the recombinant $A \beta$ aggregates exhibited distinct morphologies. Whereas PK-resistant $A \beta 38$ mainly consisted of amorphous aggregates, PK-resistant $A \beta 40$ and $A \beta 42$ preparations contained small, uniformly-sized spherical particles with a diameter of $\sim 15 \mathrm{~nm}$ (Fig. 1e). In contrast, PK-resistant A $\beta 43$ preparations consisted of larger spherical aggregates with diameters of $\sim 25-30 \mathrm{~nm}$. None of these structures were apparent in preparations containing only buffer or non-polymerized recombinant $A \beta 43$ that were processed identically. Fibrils were rarely found in any of the PK-resistant recombinant $\mathrm{A} \beta$ preparations, indicating that the polymerization conditions utilized generate predominantly pre-fibrillar aggregates.

\section{Purification of brain-derived $A \beta$ aggregates from $A D$ transgenic mice}

For comparison purposes, we also purified $A \beta$ aggregates from the brains of two AD mouse models, TgCRND8 and $A p p^{\mathrm{NL}-\mathrm{F}}$, both of which develop prominent cerebral $A \beta$ deposition as they age [11, 74]. To facilitate a direct comparison with recombinant $A \beta$ aggregates, we employed a purification protocol that also involves PK digestion, and which produces $A \beta$ seeds that are potent inducers of cerebral $A \beta$ pathology (Fig. 2a) [73, 84]. In purified preparations from TgCRND8 mice, a band corresponding to the molecular weight of $A \beta$ was the predominant species observed by SDS-PAGE followed by silver staining whereas additional high-molecular weight species were present in the preparations from $A p p^{\mathrm{NL}-\mathrm{F}}$ mice (Fig. 2b). Using the PK-resistant recombinant $A \beta$ aggregates as a reference, the $A \beta$ variant composition of the purified TgCRND8 and $A p p^{\mathrm{NL}-\mathrm{F}}$ A $\beta$ preparations was analyzed by electrophoresis using urea-containing polyacrylamide gels [82]. All four $A \beta$ peptides (A $\beta 38, A \beta 40, A \beta 42$, and $A \beta 43$ ) were present in the purified TgCRND8 A $\beta$ preparation, although the relative levels of $A \beta 40$ and $A \beta 42$ were higher than $A \beta 38$ and $A \beta 43$ (Fig. 2c), similar to what we have previously 


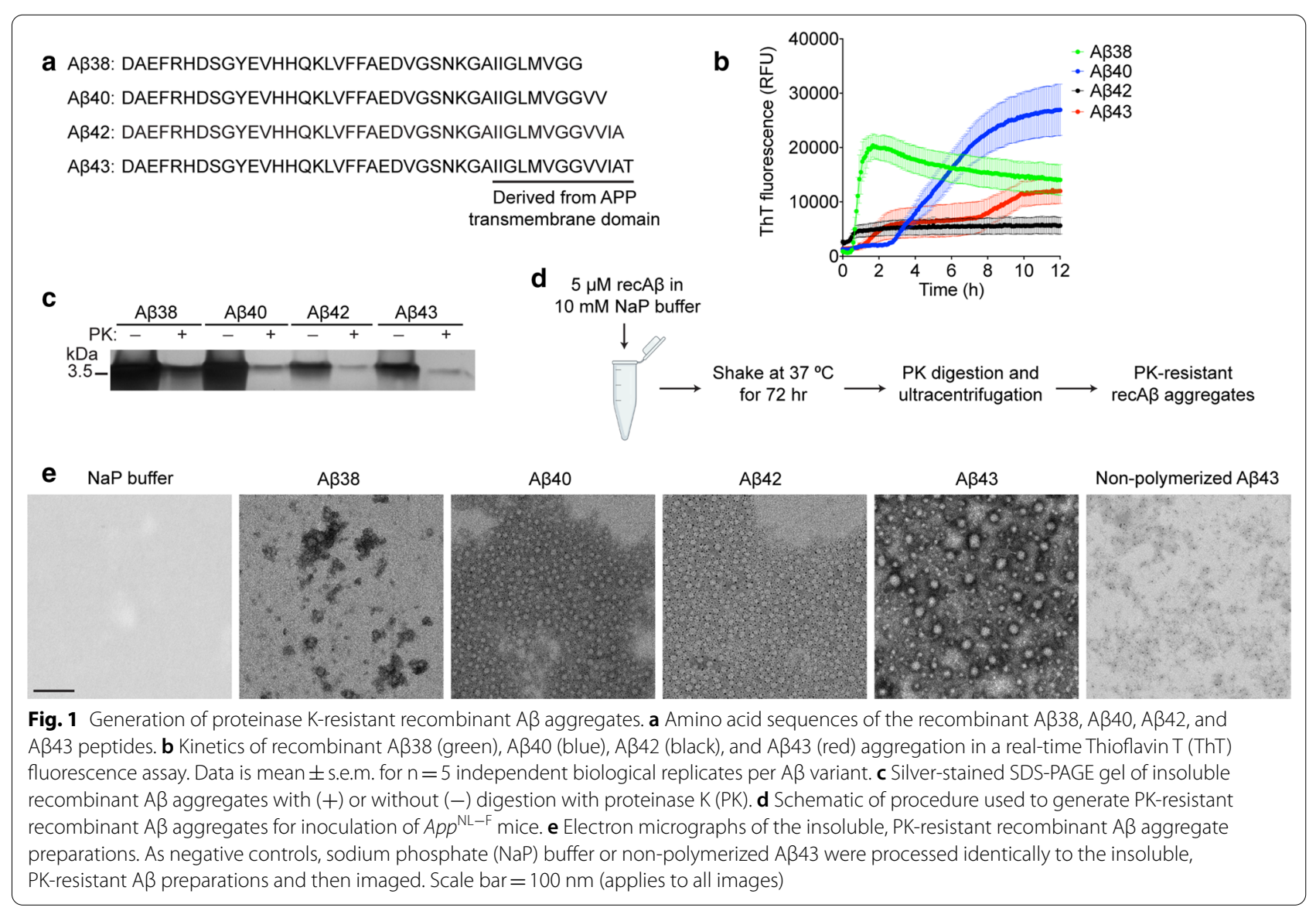

\section{a}

8-month-old TgCRND8 brain

20-month-old $A p p^{N-F}$ brains
Derived from APP

transmembrane domain

hake at $37^{\circ} \mathrm{C}$

PK digestion and PK-resistant recA $\beta$ aggregates

\section{e} preparations. As negative controls, sodium phosphate (NaP) buffer or non-polymerized A 343 were processed identically to the insoluble,

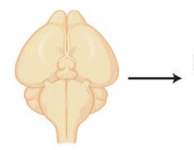
Homogenization and lysis $\longrightarrow$ Iodixanol Benzonase and PK digestion $\longrightarrow \begin{gathered}\text { Sucrose } \\ \text { cushion }\end{gathered}$ Purified brain-derived $A \beta$ aggregates

b
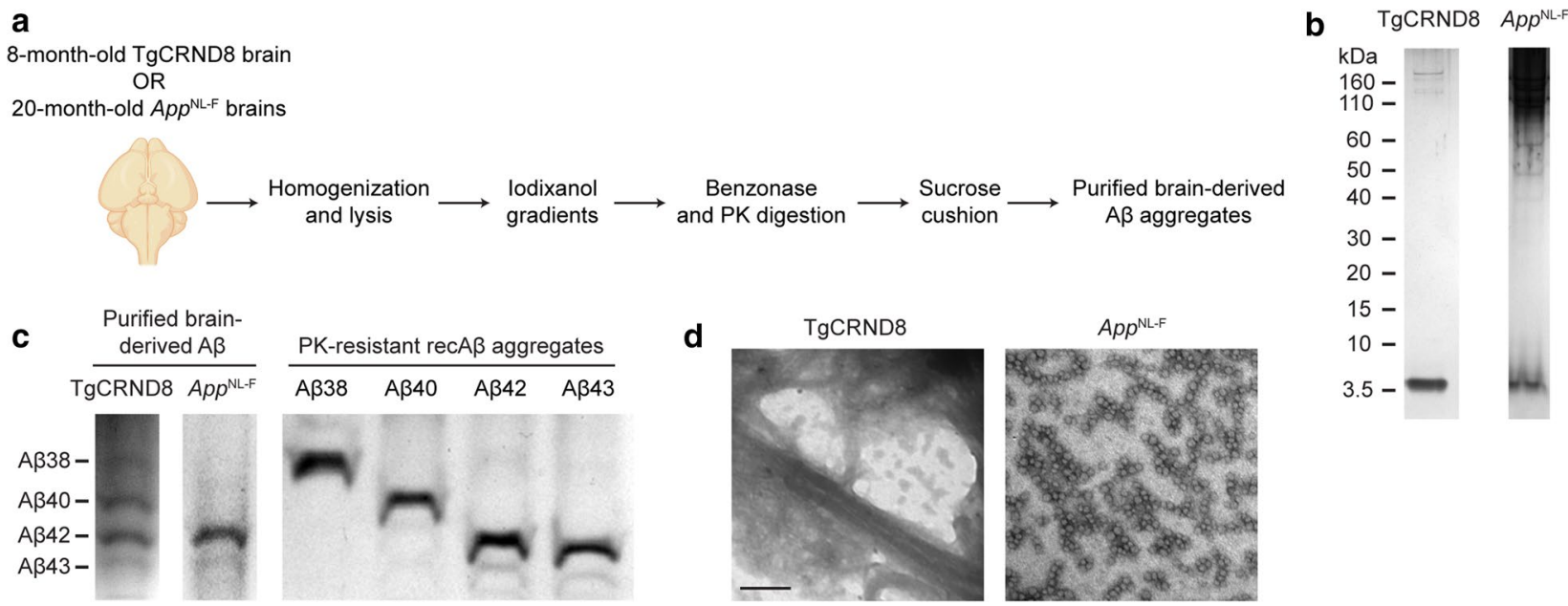

Fig. 2 Purification of brain-derived $A \beta$ aggregates from transgenic mice. a Schematic of the procedure used to purify PK-resistant $A \beta$ aggregates from the brains of aged TgCRND8 and App ${ }^{N L-F}$ mice. $\mathbf{b}$ Silver-stained SDS-PAGE of the purified A 3 aggregates from TgCRND8 and $A p p^{N L-F}$ mice. $\mathbf{c}$ Silver-stained urea gels of purified brain-derived and recombinant PK-resistant A $\beta$ aggregates. $\mathbf{d}$ Electron micrographs of PK-resistant A $\beta$ aggregates purified from the brains of TgCRND8 and $A p p^{\mathrm{NL}-\mathrm{F}}$ mice. Scale $\mathrm{bar}=100 \mathrm{~nm}$ (applies to both images) 
determined [73]. In contrast, the purified $A \beta$ fraction isolated from $A p p^{\mathrm{NL}-\mathrm{F}}$ mice consisted predominantly of $A \beta 42$ with trace amounts of $A \beta 43$. Using electron microscopy, we observed that the purified, PK-resistant $A p p^{\mathrm{NL}-\mathrm{F}}$ material was composed of $\mathrm{A} \beta$ protofibrils consisting of spherical particles arranged in linear clusters whereas the purified TgCRND8 material was mostly composed of plaques and fibrillar $A \beta$ species (Fig. 2d).

\section{Inoculation of $A p p^{N L-F}$ mice with recombinant and brain-derived $A \beta$ aggregates}

For the in vivo seeding studies, 6-week-old $A p p^{\mathrm{NL}-\mathrm{F}}$ knock-in mice were intracerebrally injected with $100 \mathrm{ng}$ of PK-resistant recombinant $A \beta$ preparations or purified brain-derived $A \beta$ aggregates (Fig. 3a). Prior to inoculation, an $A \beta_{1-x}$ ELISA was used to measure the concentration of PK-resistant $A \beta$ in each preparation to ensure that each mouse received an equal amount of
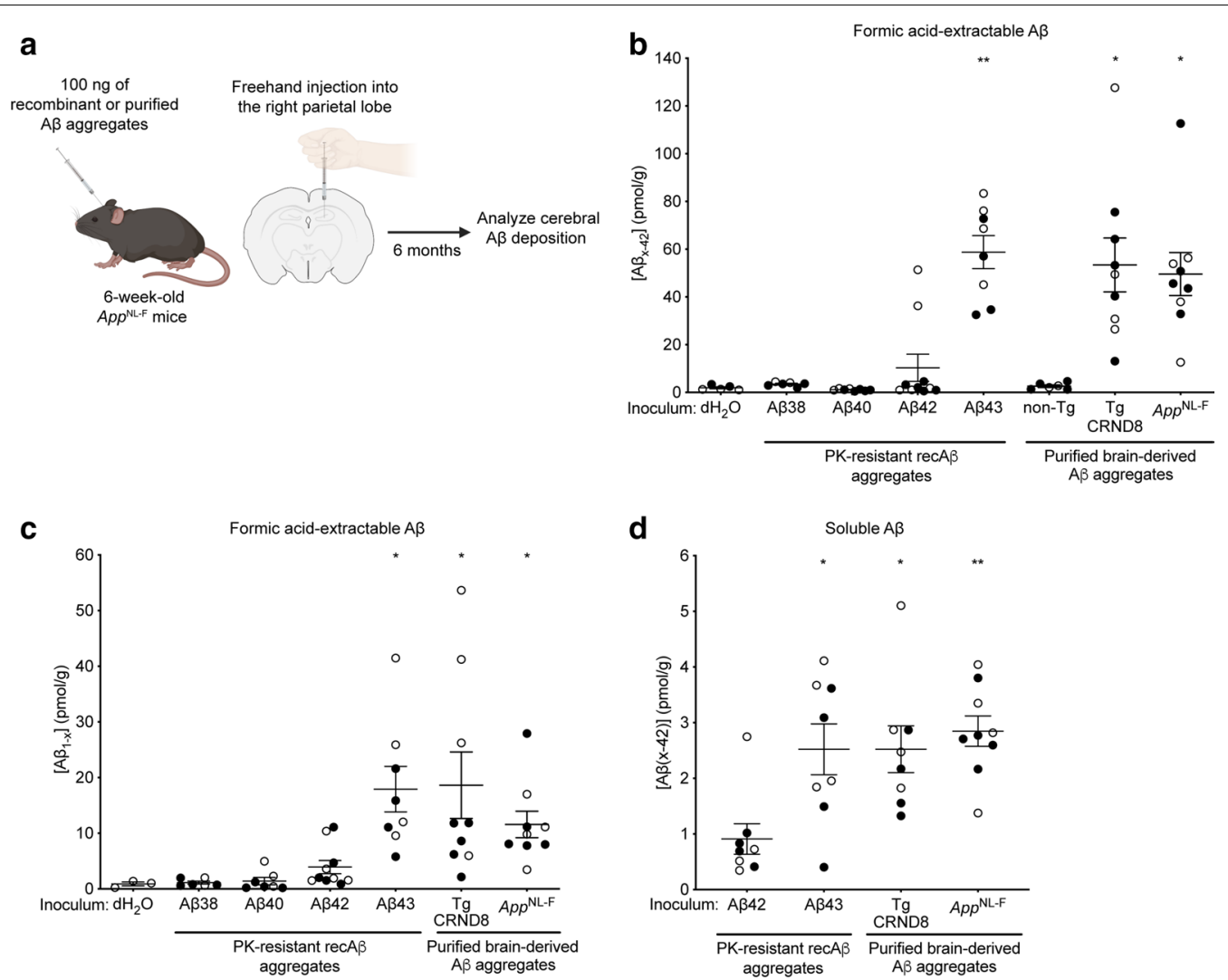

Fig. 3 Increased cerebral $A \beta 42$ levels in mice inoculated with recombinant $A \beta 43$ aggregates. a Schematic of the intracerebral inoculation procedure in $A p p^{\mathrm{NL}-\mathrm{F}}$ mice and the experimental timeline. $\mathbf{b}$ Formic acid-extractable $A \beta 42$ levels (mean \pm s.e.m.), as determined by $A \beta_{x-42} E L I S A$, in brains from $A p p^{N L-F}$ mice at 6 months post-inoculation with recombinant $A \beta$ aggregates $(n=6,8,10$, or 8 for $A \beta 38, A \beta 40, A \beta 42$, and $A \beta 43$, respectively) or purified brain-derived $A \beta$ aggregates from either TgCRND8 $(n=9)$ or $A p p^{N L-F}(n=9)$ mice. A $A 42$ levels in mice inoculated with either $\mathrm{dH}_{2} \mathrm{O}(\mathrm{n}=5)$ or material derived from a non-Tg mouse brain subjected to the $A \beta$ purification protocol $(n=6)$ are also shown. Levels of $A \beta 42$ were significantly higher in mice injected with recombinant $A \beta 43$ aggregates or brain-derived $A \beta$ aggregates compared to mice injected with $\mathrm{dH}_{2} \mathrm{O}\left(P=0.0061\right.$ for $\mathrm{A} \beta 43, P=0.018$ for TgCRND8, and $P=0.021$ for $A p p^{\mathrm{NL}-\mathrm{F}}$ as determined by a Kruskal-Wallis test followed by Dunn's multiple comparisons test; all other groups are non-significant compared to $\mathrm{dH}_{2} \mathrm{O}$-injected mice). $\mathbf{c}$ Levels of formic acid-extractable full-length total $A \beta$ (mean \pm s.e.m.), as determined by $A \beta_{1-x} E L I S A$, in brains from $A p p^{N L-F}$ mice inoculated with either $\mathrm{dH}_{2} \mathrm{O}(n=3), A \beta 38(n=6), A \beta 40(n=7), A \beta 42$ $(n=10), A \beta 43(n=8), \operatorname{TgCRND8} A \beta(n=9)$, or $A p p^{N L-F} A \beta(n=9)$. Levels of total $A \beta$ were significantly higher in mice injected with recombinant $A \beta 43$ aggregates or brain-derived $A \beta$ aggregates compared to mice injected with $\mathrm{dH}_{2} \mathrm{O}(P=0.010$ for $A \beta 43, P=0.023$ for TgCRND8, and $P=0.045$ for $A p p^{\mathrm{NL}-\mathrm{F}}$ as determined by a Kruskal-Wallis test followed by Dunn's multiple comparisons test; all other groups non-significant compared to $\mathrm{dH}_{2} \mathrm{O}$-injected mice). $\mathbf{d}$ Soluble $A \beta 42$ levels (mean \pm s.e.m.), as determined by $A \beta_{x-42}$ ELISA, in brains from $A p p^{\mathrm{NL}-\mathrm{F}}$ mice inoculated with recombinant $A \beta 42$ aggregates $(n=8)$, recombinant $A \beta 43$ aggregates $(n=8)$, TgCRND8 $A \beta$ aggregates $(n=8)$, or $A p p^{N L-F} A \beta$ aggregates $(n=9)$. Levels of soluble $A \beta 42$ were significantly higher in mice injected with recombinant $A \beta 43$ aggregates or brain-derived $A \beta$ aggregates compared to mice injected with recombinant $\mathrm{A} \beta 42$ aggregates $\left(P=0.025\right.$ for $\mathrm{A} \beta 43, P=0.039$ for TgCRND8, and $P=0.0039$ for $A p p^{\mathrm{NL}-\mathrm{F}}$ as determined by a Kruskal-Wallis test followed by Dunn's multiple comparisons test). In panels b- $d$, open circles indicate female mice and filled circles indicate male mice 
$\mathrm{A} \beta$ aggregates. As negative controls, mice were injected with either $\mathrm{dH}_{2} \mathrm{O}$ or brain material from a non-transgenic TgCRND8 littermate, henceforth referred to as non-Tg, that was subjected to the same purification protocol. Mice were injected into the right cerebral hemisphere using a freehand inoculation technique previously shown to be an effective means of introducing $A \beta$ seeds into the brain and which results in similar kinetics of induced $A \beta$ accumulation to mice injected using a stereotactic technique $[73,84,93,95]$. With the freehand technique, the $A \beta$ seeds are predominantly delivered into the hippocampus and overlying cortical regions, but it is likely that a portion of the seeds enter the ventricles as well. Mice were euthanized at 6 months post-inoculation ( 7.5 months of age), a timepoint at which minimal spontaneous $A \beta$ deposition is present in the brain [73]. Both male and female mice were analyzed since it has been shown that the kinetics of spontaneous $A \beta$ accumulation are accelerated in female AD mouse models [8]. As expected, all $A \beta$-inoculated mice remained free of overt signs of neurological illness for the duration of the experiment, although a subset of mice died of intercurrent illness (Additional file 1: Table S1) and were excluded from analysis.

Analysis of total (formic acid-extractable) $\mathrm{A} \beta$ levels in brain homogenates from the groups of inoculated mice using an ELISA specific for $A \beta$ species ending at residue $42\left(A \beta_{x-42}\right)$ revealed significant differences (Fig. $\left.3 b\right)$. Levels of cerebral $A \beta 42$ in mice injected with $A \beta 38$ or $A \beta 40$ aggregates were identical to those in mice injected with $\mathrm{dH}_{2} \mathrm{O}$ or the non-Tg mock-purified sample, suggesting that no induction of $\mathrm{A} \beta$ deposition occurred in these mice. In contrast, elevated $A \beta 42$ levels were present in $20 \%$ ( 2 of 10 ) A 342 -injected mice and $100 \%$ (8 of 8) A $\beta 43$-injected mice. Remarkably, cerebral A $\beta 42$ levels in mice injected with $A \beta 43$ aggregates were similar to those in mice injected with purified brain-derived aggregates from either TgCRND8 mice or $A p p^{\mathrm{NL}-\mathrm{F}}$ mice (Fig. 3b). There was no consistent difference in $A \beta 42$ levels between male and female $A \beta$-inoculated mice, suggesting that the presence of $A \beta$ seeds may override sex-specific differences in the kinetics of spontaneous $A \beta$ deposition, as has been noted previously [73]. Similar results were obtained when an ELISA that recognizes all $A \beta$ variants with an intact $\mathrm{N}$-terminus $\left(\mathrm{A} \beta_{1-\mathrm{x}}\right)$ was used (Fig. $3 \mathrm{c}$ ), suggesting that $A \beta 42$ is the predominant $A \beta$ species induced in the inoculated $A p p^{\mathrm{NL}-\mathrm{F}}$ mice. The lower absolute levels of $A \beta$ when measured using the $A \beta_{1-x}$ assay may reflect differential sensitivities and capture efficiencies between the two ELISAs but could also suggest that a portion of the induced $A \beta 42$ species may be $\mathrm{N}$-terminally truncated [41].
While levels of soluble $A \beta 42$ in mice inoculated with recombinant $A \beta 43$ aggregates or brain-derived $A \beta$ aggregates were $\sim 2.5$-fold higher than in mice injected with recombinant $A \beta 42$ aggregates (Fig. 3d), soluble $A \beta 42$ levels were $\sim 25$-fold lower than total $A \beta$ levels in $A \beta 43$ injected animals. Moreover, levels of PK-resistant A $\beta 42$ in $A \beta 43$-inoculated mice were not significantly different from total $\mathrm{A} \beta 42$ levels, as determined by ELISA (Fig. 4a). These results imply that the majority of cerebral A $\beta 42$ species in mice injected with $A \beta 43$ are present in an aggregated state. To further confirm the presence of A $\beta$ aggregates, we looked for the presence of detergentinsoluble, PK-resistant $A \beta$ species in brain homogenates from inoculated $A p p^{\mathrm{NL}-\mathrm{F}}$ mice. All of the mice inoculated with $A \beta 43$ aggregates exhibited PK-resistant $A \beta$ species in their brains, whereas PK-resistant $A \beta$ was detected in only 2 of 10 A $\beta 42$-inoculated animals (Additional file 2 : Fig. S1). In brain homogenates from $A \beta 43$-injected mice, PK-resistant $A \beta$ could be detected with two distinct $A \beta$ antibodies (Fig. 4b). Brain homogenates from mice injected with brain-derived $A \beta$ aggregates from either TgCRND8 or $A p p^{\mathrm{NL}-\mathrm{F}}$ mice also contained PK-resistant A $\beta$ species (Fig. 4c).

Neuropathological analysis of A $\beta$-inoculated $A p p^{\mathrm{NL}-\mathrm{F}}$ mice Small numbers of $A \beta 42$ deposits were observed in the frontal and parietal cortices of all groups of control- and A $\beta$-inoculated $A p p^{\mathrm{NL}-\mathrm{F}}$ mice, likely indicative of a minimal amount of spontaneous $A \beta$ pathology in mice of this age (Additional file 3: Fig. S2). In contrast, all mice inoculated with recombinant $\mathrm{A} \beta 43$ aggregates exhibited prominent induced $A \beta 42$ deposition in the cerebellum (Fig. $5 \mathrm{a}-\mathrm{c}$ ). A subset of $\mathrm{A} \beta 42$-inoculated mice (4 of 10) also exhibited cerebellar $A \beta$ pathology, but of a lower intensity than that seen in $A \beta 43$-injected animals. A minor amount of induced $A \beta 42$ deposition was also observed in the subcallosal region of a subset of $A \beta 43-$ inoculated $A p p^{\mathrm{NL}-\mathrm{F}}$ mice (3 of 8), which was not found in any of the A $\beta 42$-inoculated mice (Fig. 5b, c). Similar results were obtained when staining with an antibody that recognizes the $\mathrm{N}$-terminus of $A \beta$ (Additional file 4: Fig. S3). No significant $A \beta 42$ pathology was observed in the brains of mice inoculated with recombinant $A \beta 38$ or A $\beta 40$ aggregates. Taken together, these results indicate that $A \beta 43$ aggregates exhibit the highest propensity for inducing $\mathrm{A} \beta 42$ deposition in $A p p^{\mathrm{NL}-\mathrm{F}}$ mice.

Induced $A \beta 42$ deposition was also found in the brains of $A p p^{\mathrm{NL}-\mathrm{F}}$ mice injected with purified $\mathrm{A} \beta$ aggregates derived from the brains of either TgCRND8 or $A p p^{\mathrm{NL}-\mathrm{F}}$ mice when compared to mice injected with the non- $\mathrm{Tg}$ sample (Fig. 5b, c). However, unlike the robust $A \beta 42$ deposition observed in the cerebellum of mice injected with recombinant $A \beta 43$ aggregates, comparatively minor 


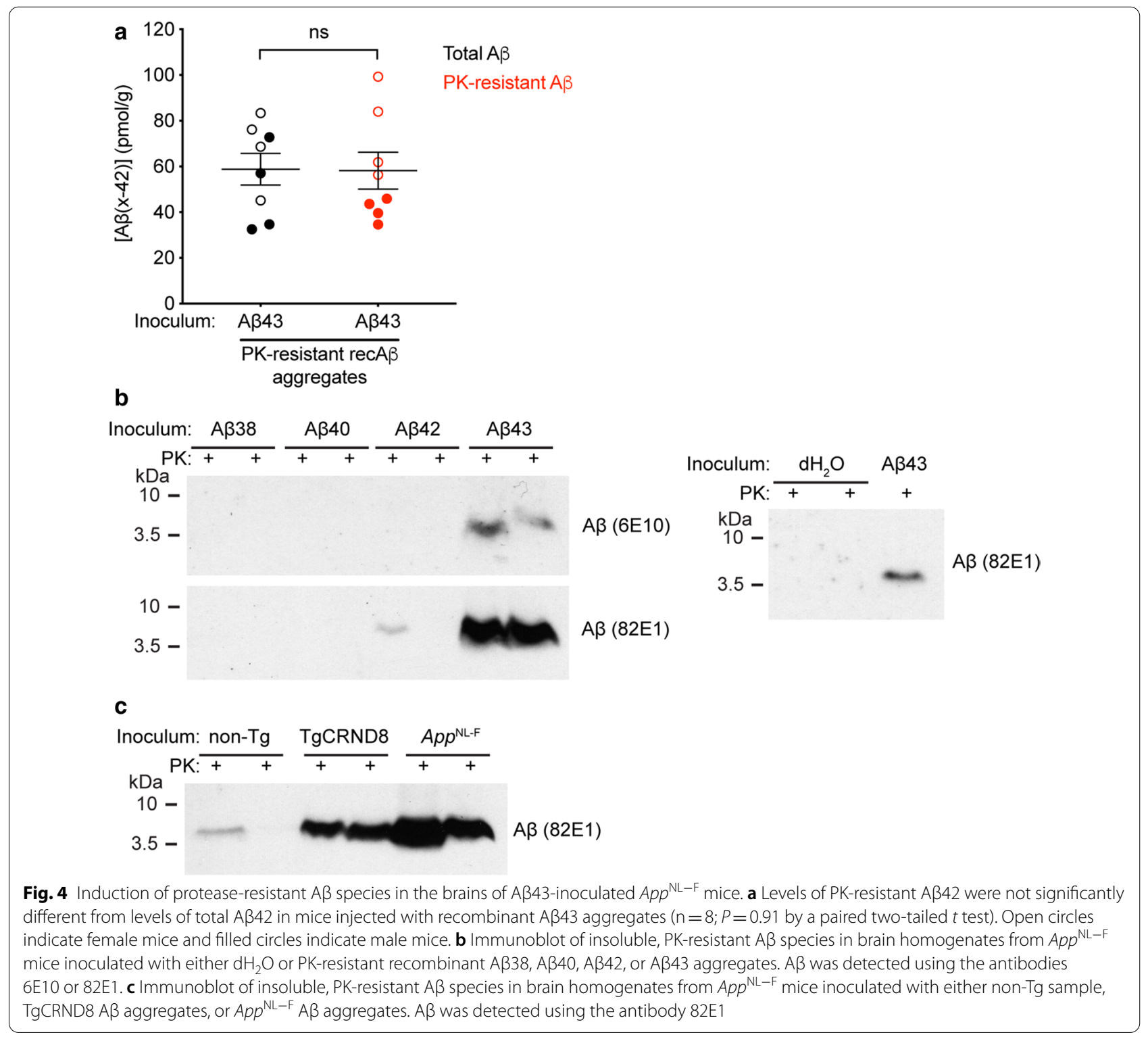

amounts of cerebellar $A \beta 42$ deposition were observed in only 5 of 9 mice injected with TgCRND8-derived A $\beta$ aggregates and only 1 of 9 mice injected with $A p p^{\mathrm{NL}-\mathrm{F}}$ derived $A \beta$. Instead, the induced $A \beta 42$ pathology in mice injected with brain-derived $A \beta$ aggregates was prominently located in the subcallosal region, similar to what we have previously described [73], as well as the occipital cortex (Fig. 5b, c). A similar pattern was observed when sections from mice inoculated with brain-derived $A \beta$ aggregates were stained with an $\mathrm{N}$-terminal $\mathrm{A} \beta$ antibody (Additional file 4: Fig. S3).

The induced $A \beta 42$ pathology in the cerebellum of $A p p^{\mathrm{NL}-\mathrm{F}}$ mice injected with recombinant $\mathrm{A} \beta 43$ aggregates was confined to the leptomeninges (Fig. 6a).
Leptomeningeal $A \beta 42$ deposition was observed in between the cerebellar folds (Fig. 6b) and at the interface between the cerebellum and the midbrain (Fig. 6c). Induced $A \beta 42$ pathology was also observed at the interface between the cortex and the midbrain (Fig. $6 \mathrm{~d}$ ). In all instances of leptomeningeal $A \beta 42$ deposition in $A \beta 43-$ inoculated mice, there was minimal to no spread of the $A \beta$ aggregates into the parenchyma. In contrast, there was robust spread of induced $A \beta 42$ pathology into the frontal and occipital cortex of $A p p^{\mathrm{NL}-\mathrm{F}}$ mice inoculated with purified $A p p^{\mathrm{NL}-\mathrm{F}} \mathrm{A} \beta$ aggregates (Fig. 6e, f). The cortical $A \beta 42$-containing plaques in the brains of mice inoculated with purified brain-derived $A \beta$ aggregates were largely diffuse in nature (Fig. 6g). 


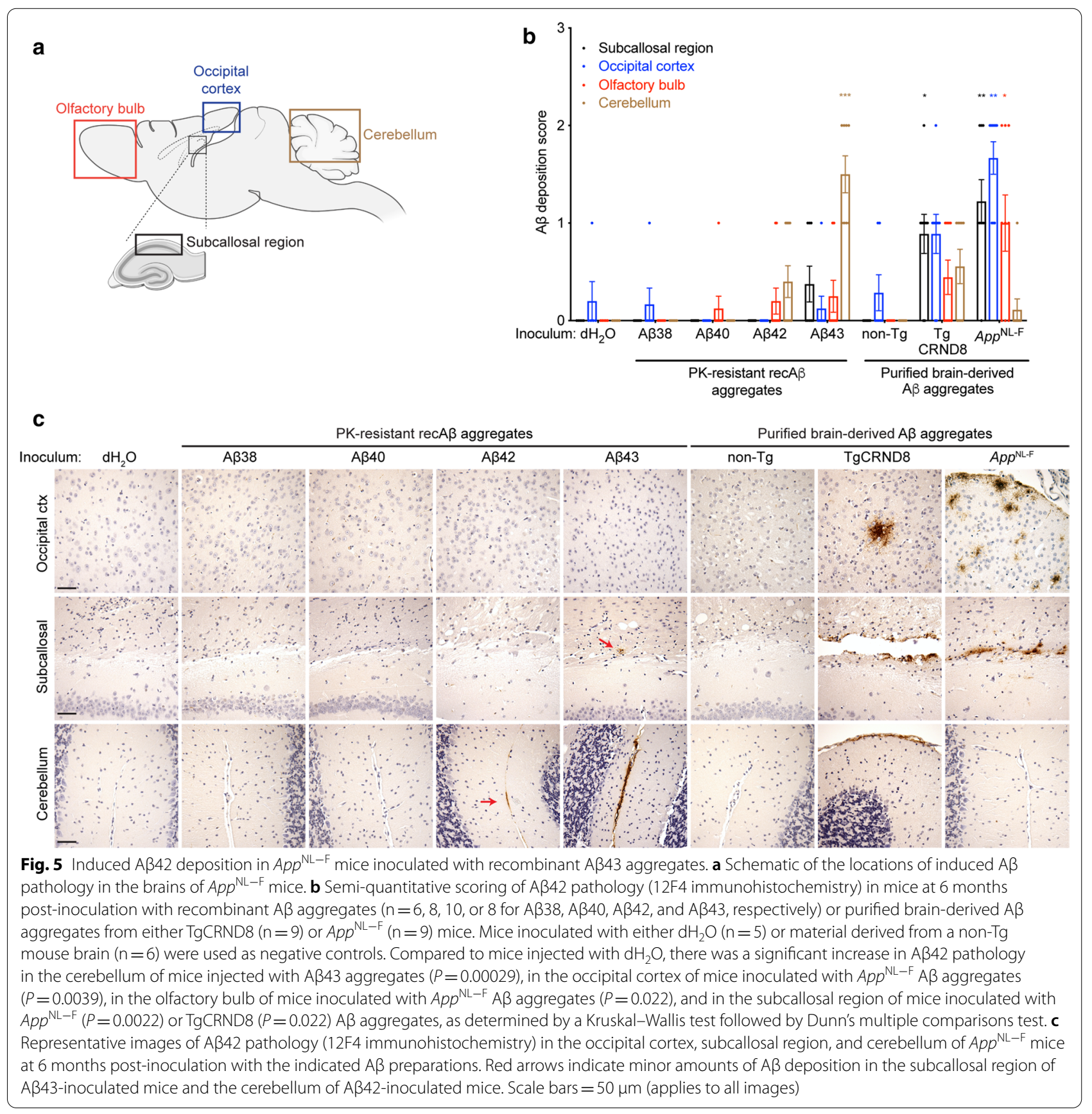

In line with our prior findings in $A \beta$-inoculated $A p p^{\mathrm{NL}-\mathrm{F}}$ mice [73], prominent $\mathrm{A} \beta 42$-containing CAA in the leptomeningeal arteries was also observed in all mice inoculated with $\mathrm{A} \beta 43, \operatorname{TgCRND} 8 \mathrm{~A} \beta$, or $A p p^{\mathrm{NL}-\mathrm{F}}$ $A \beta$ aggregates (Fig. $7 a-c$ ). In mice injected with $A \beta 42$ aggregates, moderate leptomeningeal A $\beta 42$ CAA was present in $60 \%$ of the animals, whereas only one mouse each in the groups inoculated with either $A \beta 38$ or $A \beta 40$ aggregates exhibited detectable CAA (Fig. 7b, c). Cortical
$A \beta 42$ CAA was also observed in mice injected with $A \beta 42$, $\mathrm{A} \beta 43, \operatorname{TgCRND} 8 \mathrm{~A} \beta$, or $A p p^{\mathrm{NL}-\mathrm{F}} \mathrm{A} \beta$ aggregates (Fig. 7c), but this was much less prominent than the leptomeningeal CAA. None of the control-inoculated mice exhibited any $A$ B 42 -containing leptomeningeal $C A A$, suggesting that spontaneous A $\beta$ CAA is not common in $A p p^{\mathrm{NL}-\mathrm{F}}$ mice at this age. While $A \beta 40$ is the principal component of $\mathrm{CAA}$ in $\mathrm{AD}$ [9], the presence of $\mathrm{A} \beta 42$ in the leptomeningeal blood vessels of $\mathrm{A} \beta$-inoculated $A p p^{\mathrm{NL}-\mathrm{F}}$ mice 


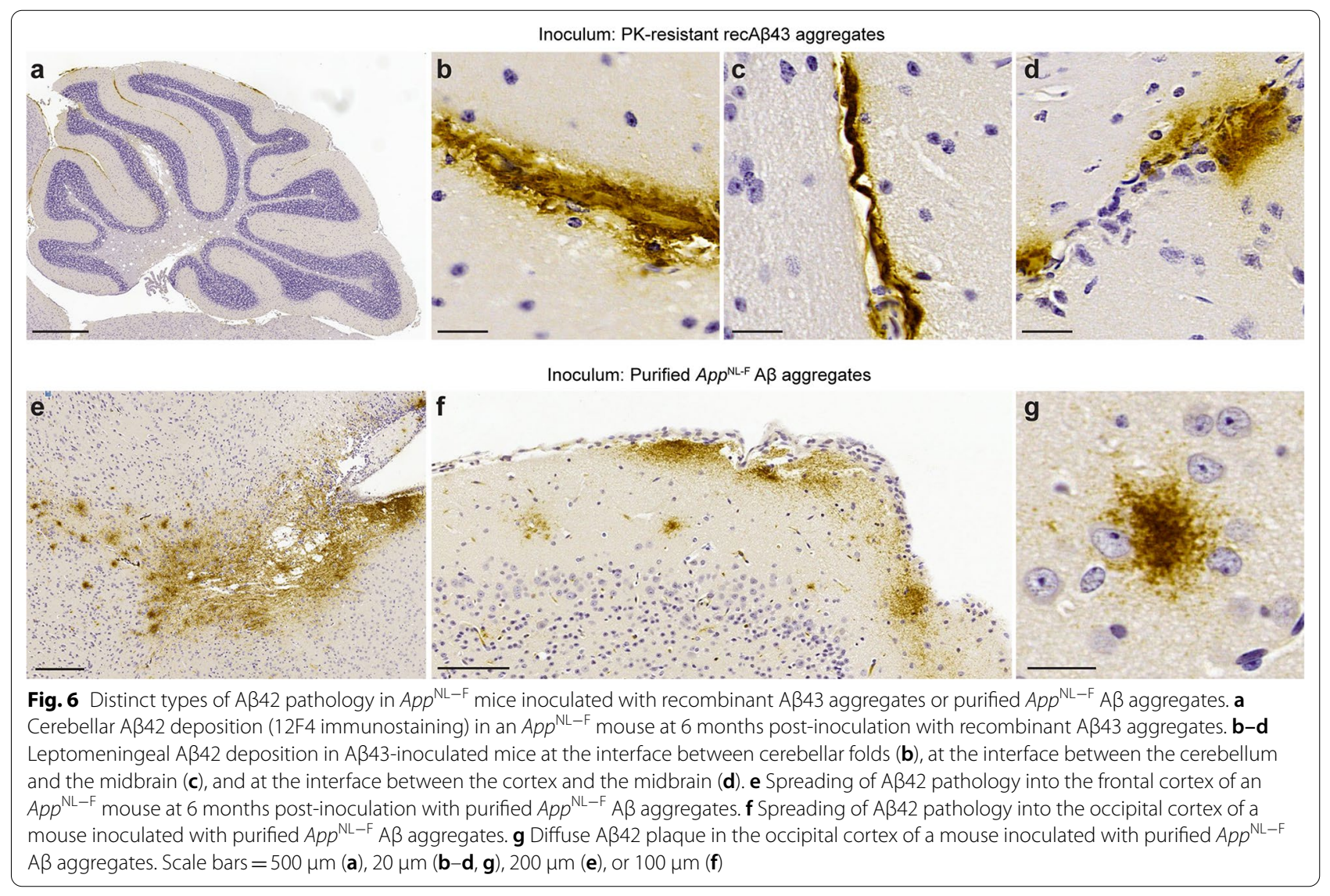

likely reflects the presence of the Iberian/Beyreuther $A P P$ mutation, which results in a large increase in the $\mathrm{A} \beta 42: \mathrm{A} \beta 40$ ratio $[22,51]$.

\section{Conformational analysis of recombinant $A \beta$ aggregates}

Given the markedly different in vivo seeding activities observed between $A \beta$ aggregates composed of different $\mathrm{A} \beta \mathrm{C}$-terminal variants, we asked whether this may be due in part to conformational differences among the aggregates. For these studies, we generated recombinant $A \beta$ aggregates as before but we did not isolate the PK-resistant fraction prior to analysis (Fig. 8a). We first assessed fluorescence emission spectra upon binding of the conformation-sensitive dyes curcumin and heptamer-formyl thiophene acetic acid (hFTAA) to the various $A \beta$ aggregates $[13,36,61,70]$. While the curcumin emission spectra for $A \beta 40, A \beta 42$, and $A \beta 43$ aggregates were essentially superimposable, the curve for $A \beta 38$ aggregates was red-shifted, with a significantly higher $\lambda_{\max }$ value (Fig. $8 \mathrm{~b}$ ). With hFTAA, the emission spectrum for $A \beta 43$ aggregates differed from the other three, with a reduced second peak around $600 \mathrm{~nm}$ (Fig. 8c). All of the $\mathrm{A} \beta$ aggregates were highly resistant to PK digestion, even up to concentrations of $2 \mathrm{mg} / \mathrm{mL}$ PK (Fig. 8d). To further characterize the conformational properties of the recombinant $A \beta$ aggregates, we performed conformational stability assays, which measure the relative resistance of the aggregates to denaturation with guanidine hydrochloride [46]. While none of the aggregates was fully solubilized by $6 \mathrm{M}$ guanidine hydrochloride, $A \beta 40$ and $A \beta 43$ aggregates were significantly less stable than either $A \beta 38$ or A 342 aggregates (Fig. 7e). Collectively, these results suggest that while all four $\mathrm{A} \beta \mathrm{C}$-terminal variants form highly PK-resistant aggregates, conformational differences may exist among them.

\section{Discussion}

In this study, we investigated the relative prion-like seeding capacities of individual $A \beta C$-terminal variants in the $A p p^{\mathrm{NL}-\mathrm{F}}$ AD mouse model using aggregates composed of recombinant $\mathrm{A} \beta$. Given that $A p p^{\mathrm{NL}-\mathrm{F}}$ mice predominantly produce $A \beta 42$ [74] and that nucleation-dependent polymerization is generally most efficient when the seed and substrate are composed of identical protein species, we had predicted that recombinant $A \beta 42$ aggregates would exhibit higher seeding propensity than $A \beta 38, A \beta 40$, or $A \beta 43$ aggregates. Instead, we found that $A \beta 43$ aggregates were the most potent seeds and were 


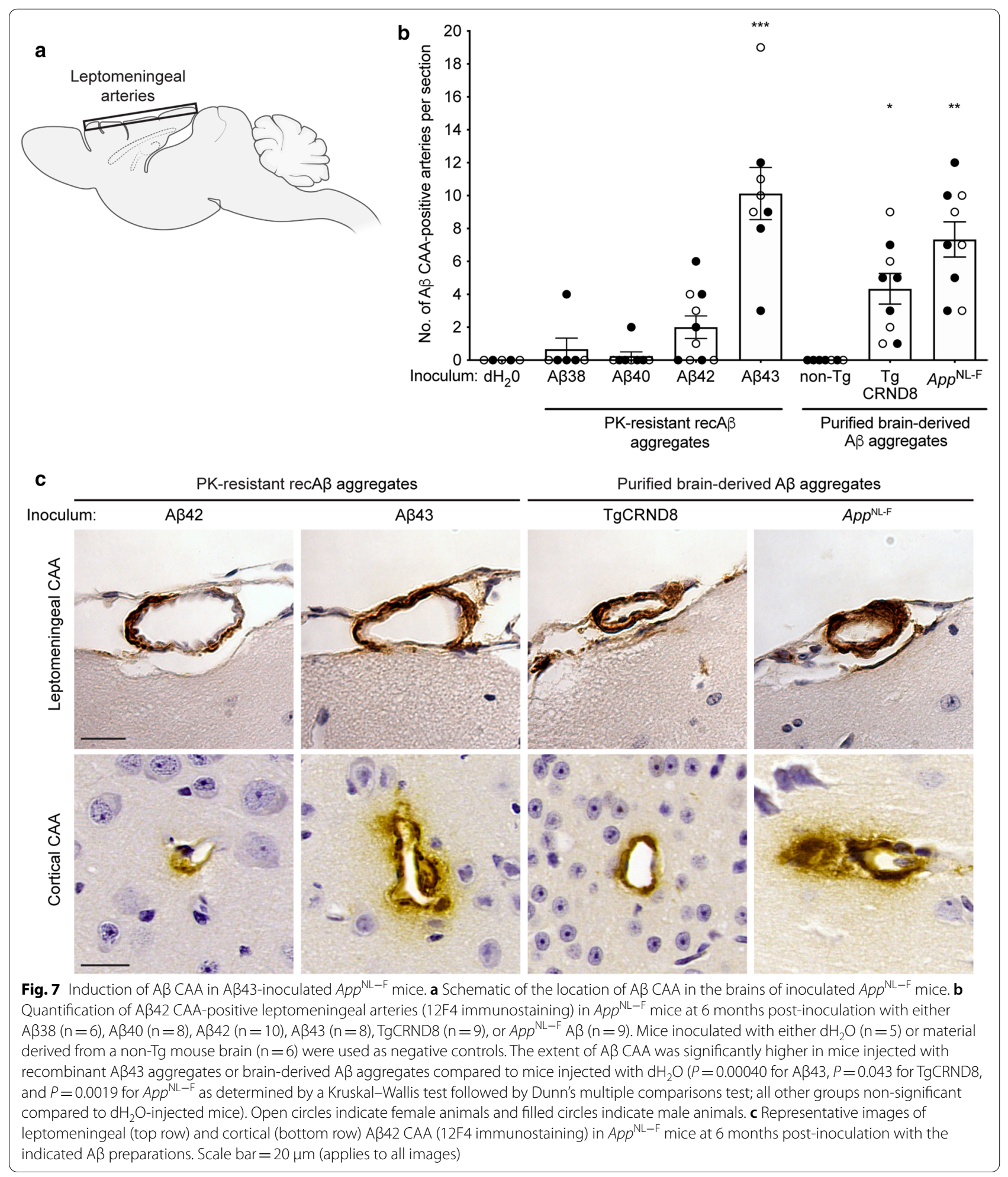

as effective as brain-derived $A \beta$ aggregates at inducing the accumulation and deposition of $A \beta 42$ in the brain. A subset of mice inoculated with $A \beta 42$ aggregates also exhibited some induced $A \beta 42$ deposition and pathology, suggesting the existence of a "seeding capacity gradient" in which $A \beta 43$ would be the peptide with the highest seeding capacity followed by $A \beta 42$, with $A \beta 40$ and $A \beta 38$ falling in the ineffectual range. It is noteworthy that the 


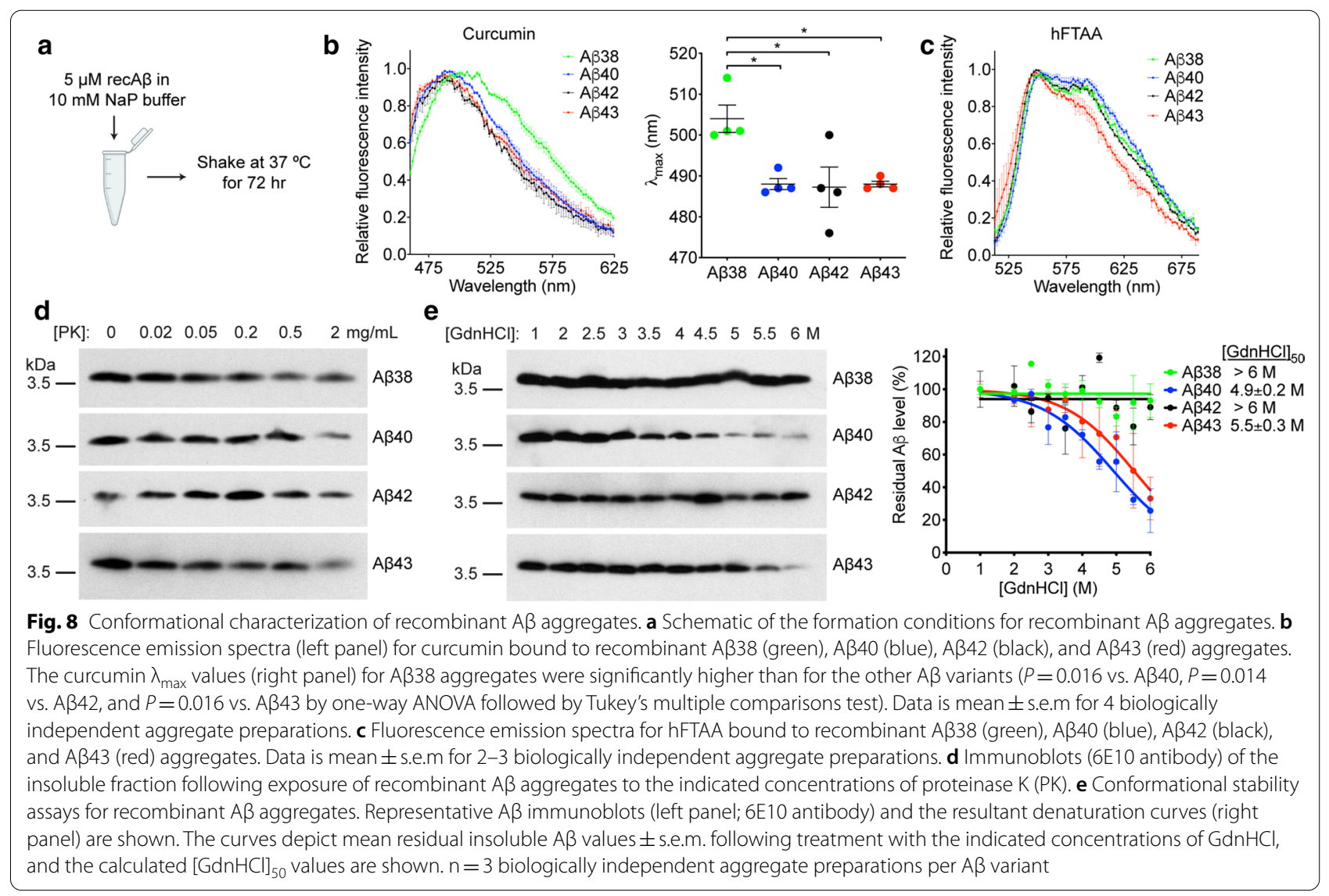

purified brain-derived $\mathrm{A} \beta$ aggregates from TgCRND8 and $A p p^{\mathrm{NL}-\mathrm{F}}$ mice both contained detectable amounts of A 343 . While it is not possible at this time to ascribe the seeding activity present in these samples to $A \beta 43$, the lack of detectable $A \beta 40$ and $A \beta 38$ in the purified $A p p^{\mathrm{NL}-\mathrm{F}}$ aggregates and the comparable seeding activity of $A p p^{\mathrm{NL}-\mathrm{F}} \mathrm{A} \beta$ aggregates to TgCRND8 A $\beta$ aggregates suggests that longer $A \beta$ variants are more important for the observed seeding behavior than shorter variants.

Previous studies revealed that synthetic A $\beta 40$ and $A \beta 42$ aggregates are capable of inducing cerebral $A \beta$ pathology in a transgenic AD mouse model [83, 84], whereas we did not observe any seeding activity with recombinant A 340 aggregates and only marginal activity with $A \beta 42$ aggregates. The simplest explanation for this discrepancy relates to the amount of $A \beta$ aggregates injected into the mice. In our study, mice received $100 \mathrm{ng}$ of recombinant $A \beta$ aggregates whereas in the previous studies mice received 7.5 or $12 \mu \mathrm{g}$ of $\mathrm{A} \beta$, a 75 - to 120 -fold difference. Indeed, the efficiency of $A \beta$ pathology induction in mice is known to be directly proportional to the amount of seed material injected [56]. Furthermore, in the previous studies, the induction of cerebral $A \beta$ deposition was assessed at 11 months post-inoculation whereas we analyzed the $A \beta$-injected mice at 6 months post-inoculation to minimize the co-occurrence of spontaneous $A \beta$ pathology. This extra time may have permitted the amplification and propagation of $A \beta$ seeds that were initially in low abundance. Finally, it should be noted that a different AD mouse model was used in the aforementioned studies. APP23 transgenic mice express APP containing only the Swedish mutation and thus, at all ages, produce more A $\beta 40$ than $A \beta 42[85,97]$, which might render the mice more susceptible to $\mathrm{A} \beta 40$ seeds.

Inoculation of $A p p^{\mathrm{NL}-\mathrm{F}}$ mice with recombinant $\mathrm{A} \beta 43$ aggregates resulted in a similar amount of cerebral A $\beta 42$ accumulation as in mice injected with identical quantities of brain-derived $A \beta$ aggregates, suggesting that $A \beta 43$ facilitates the in vitro generation of $A \beta$ aggregates with seeding activities comparable to brain-derived material. Previous studies had determined that synthetic A $\beta 40$ aggregates were approximately 100 -fold less potent than brain-derived $A \beta$ aggregates at inducing $A \beta$ pathology in the mouse brain [84]. A potential explanation for this difference is that synthetic and brain-derived $A \beta 40$ aggregates are structurally distinct and thus constitute distinct $A \beta$ strains $[38,45]$. We speculate that recombinant $A \beta 43$ aggregates adopt a structure that is more 
similar to brain-derived $A \beta$ aggregates than can be obtained by polymerization of $A \beta 40$ or $A \beta 42$ in vitro. However, the structures of recombinant $A \beta 43$ and brainderived $A \beta$ aggregates must not be identical, as the two types of $A \beta$ assemblies produced distinct neuropathological signatures upon inoculation in mice and thus may comprise unique strains. In particular, prominent cerebellar $A \beta$ deposition within the leptomeninges was observed in mice injected with recombinant $A \beta 43$ aggregates. Interestingly, this pattern resembled that observed when $A p p^{\mathrm{NL}-\mathrm{F}}$ mice were injected with archival batches of cadaveric human growth hormone that produced a CAA-dominant A $\beta$ pathology when administered to humans [68]. Since CAA was also a striking feature in A 343 -inoculated mice, the structure of recombinant A $\beta 43$ aggregates may share some characteristics with the $\mathrm{A} \beta$ seeds present in the growth hormone preparations.

While a molecular explanation for the differential distribution of $A \beta$ pathology induced by recombinant $A \beta 43$ and brain-derived $A \beta$ aggregates remains to be determined, we hypothesize that it may be related to the relative ability of the aggregates to migrate into the parenchyma. Using the freehand inoculation technique, it is likely that a portion of the $A \beta$ seeds were introduced into the ventricles, resulting in their widespread distribution throughout the brain via CSF circulation pathways. Brain-derived $A \beta$ seeds may be better at templating the production of $A \beta$ aggregates that are capable of entering the parenchyma, which is consistent with our observation that the majority of induced parenchymal $A \beta$ pathology in mice injected with brain-derived seeds was found in proximity to the surface of the brain or in the vicinity of the ventricular system. In contrast, the $A \beta$ pathology induced by recombinant $A \beta 43$ seeds may remain confined to the leptomeninges because they are unable to spread into the parenchyma. The reason for this differential spread may be related to the size of the induced $A \beta$ aggregates [43] or the differential affinity of recombinant and brain-derived $A \beta$ aggregates for putative $A \beta$ receptors that may be required for transit from the leptomeninges into the parenchyma $[35,47]$.

We envision two possible explanations for the differential seeding activities observed for aggregates composed of distinct $A \beta C$-terminal variants, although these are not mutually exclusive. First, A $\beta 43$ aggregates may consist of a unique structure that exhibits a higher propensity for self-propagation in vivo. Under the polymerization conditions we employed, the PK-resistant A $\beta 43$ aggregates adopted a pre-fibrillar structure, which was distinct from those present in the $A \beta 38, A \beta 40$, and $A \beta 42$ preparations as well as the protofibrils and fibrils present in the brain-derived $\mathrm{A} \beta$ preparations. We also note that recombinant $A \beta 43$ aggregates exhibited a distinct spectral signature when bound to hFTAA, arguing for structural variances among the different aggregate preparations. A second possibility is that $A \beta 43$ aggregates are either more or less stable upon injection into mice than the other $A \beta$ aggregates. In prion disease, less stable prion strains replicate more quickly in animals, and $A \beta$ aggregates with lower stability appear to propagate more rapidly in mice $[50,94]$. Since the A $\beta 43$ aggregates were more susceptible to denaturation with guanidine hydrochloride than A 342 aggregates, they may be more frangible and thus generate a greater quantity of seeds when injected into mice. On the other hand, it is plausible that exogenous A $\beta 43$ aggregates may be cleared at a slower rate in vivo, which may permit prolonged exposure to $A \beta$ seeds and therefore increased $\mathrm{A} \beta$ propagation.

We do not know whether the enhanced seeding activity of the $A \beta 43$ aggregates was due to the specific $A \beta$ assembly state formed using these conditions or whether multiple types of A 343 assemblies (oligomers, protofibrils, fibrils, etc.) all exhibit heightened prion-like seeding behavior. A limitation of our study is that we only used a single set of conditions to generate the recombinant $\mathrm{A} \beta$ aggregates. It is widely documented that varying the buffer and polymerization conditions can lead to the formation of structurally distinct A $\beta$ "polymorphs" $[37,53$, 66]. Indeed, while we polymerized $A \beta 43$ at a concentration of $5 \mu \mathrm{M}$ in sodium phosphate buffer to obtain PKresistant pre-fibrillar aggregates [83], polymerization of $\mathrm{A} \beta 43$ at a concentration of $10 \mu \mathrm{M}$ in phosphate-buffered saline resulted in the generation of $A \beta 43$ fibrils [10]. It will also be important to investigate the seeding activity of recombinant A 343 aggregates in other APP mouse models, including those that lack the Iberian/Beyreuther mutation and thus produce an ensemble of $\mathrm{A} \beta \mathrm{C}$-terminal variants that better resembles that observed in sporadic/late-onset $\mathrm{AD}$.

To date, a majority of studies have focused on the two most abundant variants of $A \beta, A \beta 40$ and $A \beta 42$, with the evidence pointing to $A \beta 42$ as the key mediator of $A D$ pathogenesis since it is more prone to aggregate into neurotoxic species $[29,42]$ and its levels are selectively increased by $\mathrm{AD}$-causing mutations in the presenilin genes [12, 16, 78]. However, a potential important role for $A \beta 43$ in $A D$ is becoming increasingly recognized. Unlike $A \beta 42$, which is derived from $A \beta 48$ via $A \beta 45$ by sequential presenilin cleavage, $A \beta 43$ is generated from $\mathrm{A} \beta 49$ via $\mathrm{A} \beta 46$ [86]. Once $\mathrm{A} \beta 43$-specific antibodies became available, it was discovered that $A \beta 43$ levels are increased and $\mathrm{A} \beta 43$ deposits are abundant in AD and 
Down syndrome brains, despite low absolute amounts of the peptide relative to $A \beta 40$ and $A \beta 42[26,27,65$, $77,96]$. Moreover, like $A \beta 42, A \beta 43$ readily forms aggregates in vitro and in vivo that are neurotoxic $[5,7,14$, $54,76,79]$, and lower levels of $A \beta 43$ in the cerebrospinal fluid of AD patients seems to be strongly correlated with cerebral $A \beta$ deposition in the same way as lower levels of $A \beta 42[1,48]$.

While it is conceivable that $\mathrm{N}$-terminal modifications in $A \beta$ such as truncation and pyroglutamylation at residue 3 may further modulate seeding activity [60], our data suggests that $A \beta 43$ aggregates with an intact $\mathrm{N}$-terminus possess significant seeding activity and thus may be crucial for initiating the propagation of $A \beta$ pathology during $A D$ pathogenesis. In support of this theory, $A \beta 43$ is common in diffuse plaques and is preferentially found in the core region of amyloid $A \beta$ plaques, suggesting that it might deposit early during plaque formation $[27,96]$. Furthermore, $A \beta 43$ is the earliest-depositing $A \beta$ species in the brains of an AD transgenic mouse model that expresses mutant APP [98]. Certain mutations in presenilin-1, including the AD-causing $\mathrm{L} 435 \mathrm{~F}$ and $\mathrm{R} 278 \mathrm{I}$ variants, also cause increased production of $A \beta 43$ at the expense of $A \beta 40$ and $A \beta 42[34,40,59,62,76,87,91]$. This supports a model in which early $A \beta 43$ aggregate seeds drive the downstream formation and propagation of $A \beta$ aggregates containing other $A \beta$ species, such as $A \beta 42$ and $\mathrm{A} \beta 40$. While there are conflicting results about the cross-seeding of $A \beta 42$ by $A \beta 43$ aggregates in vitro [10, $14]$, our results argue that $A \beta 43$ aggregates can act as a scaffold for the aggregation of $A \beta 42$ in vivo since A $\beta 42$ levels and deposition were greatly increased in $A p p^{\mathrm{NL}-\mathrm{F}}$ mice inoculated with $\mathrm{A} \beta 43$. Consistent with this notion, expression of $A \beta 43$ in Drosophila triggers aggregation of the normally soluble $A \beta 40$ [7].

Our findings suggest that targeting $A \beta 43$-containing seeds, potentially via immunotherapy or by reducing A 343 production, may be an effective means of halting the propagation of $A \beta$ aggregates in the early stages of $A D$. Indeed, $A \beta 42$ peptide immunization studies in $A D$ patients have revealed that $A \beta 43$-positive plaques can be cleared without a concomitant increase in vascular $A \beta 43$ deposition [28], and the increased $A \beta 43$ levels generated by mutant presenilin-1 alleles can be counteracted using small molecule $\gamma$-secretase modulators [89]. The therapeutic antibody aducanumab, which selectively recognizes $A \beta$ aggregates including soluble oligomers and insoluble fibrils [81], is able to intercept early pre-amyloid $A \beta$ seeds and reduce the development of cerebral $A \beta$ pathology in mice [90], revealing that targeting $A \beta$ seeds may have clinical benefit in AD patients.

\section{Supplementary Information}

The online version contains supplementary material available at https://doi. org/10.1186/s40478-021-01187-6.

Additional file 1: Supplementary Table 1.

Additional file 2: Supplementary Fig. 1. Determining the presence of protease-resistant $A \beta$ species in the brains of $A \beta 42$ - and $A \beta 43$-inoculated $A p P^{\mathrm{NL}-\mathrm{F}}$ mice. Immunoblot of insoluble, PK-resistant $A \beta$ species in brain homogenates from $A p p^{\mathrm{NL}-\mathrm{F}}$ mice inoculated with PK-resistant recombinant $A \beta 42$ (a) or $A \beta 43$ (b) aggregates. $A \beta$ was detected using the antibody $82 \mathrm{E} 1$

Additional file 3: Supplementary Fig. 2. Spontaneous $A \beta$ deposition in $A p p^{\mathrm{NL}-\mathrm{F}}$ mice. a Schematic of the location of spontaneous $A \beta$ pathology in the brains of $A p p^{\mathrm{NL}-\mathrm{F}}$ mice at $\sim 7.5$ months of age. $\mathbf{b}$ Quantification of Aß42 plaques (number of plaques per sagittal section) in the frontal/parietal cortex of inoculated $A p p^{\mathrm{NL}-\mathrm{F}}$ mice at 6 months post-inoculation with either $A \beta 38(n=6), A \beta 40(n=8), A \beta 42(n=10), A \beta 43(n=8), \operatorname{TgCRND} 8$ $A \beta(n=9)$, or $A p p^{N L-F} A \beta(n=9)$. Mice inoculated with either $\mathrm{dH}_{2} \mathrm{O}(\mathrm{n}=$ 5 ) or material derived from a non-Tg mouse brain $(n=6)$ were used as negative controls. There was no significant difference between the groups of inoculated mice ( $P=0.69$ by a Kruskal-Wallis test). Open circles indicate female animals and filled circles indicate male animals. c Representative images of small A 342 plaques (red arrows; $12 \mathrm{~F} 4$ immunohistochemistry) in the frontal/parietal cortex of $A p p^{\mathrm{NL}-\mathrm{F}}$ mice at 6 months post-inoculation with either $\mathrm{dH}_{2} \mathrm{O}$ or PK-resistant recombinant $A \beta$ aggregates. Scale bar $=$ $50 \mu \mathrm{m}$ (applies to all images)

Additional file 4: Supplementary Fig. 3. Deposition of full-length $A B$ species in the brains of $A \beta$-inoculated $A p p^{\mathrm{NL}-\mathrm{F}}$ mice. Representative images of full-length $A \beta$ deposition (82E1 immunohistochemistry) in the indicated brain regions of $A p p^{\mathrm{NL}-\mathrm{F}}$ mice at 6 months post-inoculation with either PK-resistant recombinant A $\beta 43$ aggregates, purified TgCRND8 A $\beta$ aggregates, or purified $A p p^{\mathrm{NL}-\mathrm{F}} A \beta$ aggregates. Scale bar $=50 \mu \mathrm{m}$ (applies to all images)

\section{Acknowledgements}

We thank Takashi Saito and Takaomi Saido for graciously providing the App $p^{\mathrm{NL}-\mathrm{F}}$ mice, Yan Chen for help with electron microscopy, and Zhilan Wang for assistance with immunohistochemistry.

\section{Authors' contributions}

All authors contributed to the study conception and design. Material preparation, data collection and analysis were performed by Alejandro Ruiz-Riquelme, Alison Mao, Marim M. Barghash, Heather H.C. Lau, Erica Stuart, K. Peter R. Nilsson and Joel C. Watts. The first draft of the manuscript was written by Alejandro Ruiz-Riquelme and Joel C. Watts, and all authors commented on previous versions of the manuscript. All authors read and approved the final manuscript.

\section{Funding}

This work was supported by operating grants from the Canadian Institutes of Health Research (MOP-136899 and PJT-173497), a New Investigator Grant from Alzheimer Society Canada/Brain Canada (16-13), and a Consolidator Grant from the Swedish Research Council (Grant No. 2016-00748). The funding bodies had no role in the design of the study, the collection, analysis, or interpretation of data, or the writing of the manuscript.

\section{Availability of data and material}

All data generated or analyzed during this study are included in this published article.

\section{Declarations}

\section{Competing interests}

The authors have no relevant financial or non-financial interests to disclose. 


\section{Ethics approval and consent to participate}

All mouse experiments were performed in accordance with guidelines set by the Canadian Council on Animal Care under a protocol (AUP \#4263.11) approved by the University Health Network Animal Care Committee.

\section{Consent for publication}

Not applicable.

\section{Author details}

${ }^{1}$ Tanz Centre for Research in Neurodegenerative Diseases, University of Toronto, Krembil Discovery Tower, Rm. 4KD481, 60 Leonard Ave., Toronto, ON M5T 0S8, Canada. ${ }^{2}$ Department of Biochemistry, University of Toronto, Toronto, ON, Canada. ${ }^{3}$ Department of Laboratory Medicine and Pathobiology, University of Toronto, Toronto, ON, Canada. ${ }^{4}$ Laboratory Medicine Program and Krembil Brain Institute, University Health Network, Toronto, ON, Canada. ${ }^{5}$ Department of Physics, Chemistry, and Biology, Linköping University, Linköping, Sweden. ${ }^{6}$ Department of Medical Biophysics, University of Toronto, Toronto, ON, Canada. ${ }^{7}$ Present Address: UK Dementia Research Institute, University College London, London, UK.
\end{abstract}

Received: 20 April 2021 Accepted: 24 April 2021

Published online: 10 May 2021

\section{References}

1. Almdahl IS, Lauridsen C, Selnes P, Kalheim LF, Coello C, Gajdzik B, Moller I, Wettergreen M, Grambaite R, Bjornerud A et al (2017) Cerebrospinal fluid levels of amyloid beta 1-43 mirror 1-42 in relation to imaging biomarkers of Alzheimer's disease. Front Aging Neurosci 9:9. https://doi.org/10.3389/ fnagi.2017.00009

2. Asher DM, Belay E, Bigio E, Brandner S, Brubaker SA, Caughey B, Clark B, Damon I, Diamond M, Freund M et al (2020) Risk of transmissibility from neurodegenerative disease-associated proteins: experimental knowns and unknowns. J Neuropathol Exp Neurol 79:1141-1146. https://doi.org/ 10.1093/jnen/nlaa109

3. Banerjee $\mathrm{G}$, Adams ME, Jaunmuktane Z, Alistair Lammie G, Turner B, Wani M, Sawhney IMS, Houlden H, Mead S, Brandner S et al (2019) Early onset cerebral amyloid angiopathy following childhood exposure to cadaveric dura. Ann Neurol 85:284-290. https://doi.org/10.1002/ana.25407

4. Benilova I, Karran E, De Strooper B (2012) The toxic Abeta oligomer and Alzheimer's disease: an emperor in need of clothes. Nat Neurosci 15:349-357. https://doi.org/10.1038/nn.3028

5. Bitan G, Kirkitadze MD, Lomakin A, Vollers SS, Benedek GB, Teplow DB (2003) Amyloid beta -protein (Abeta) assembly: Abeta 40 and Abeta 42 oligomerize through distinct pathways. Proc Natl Acad Sci U S A 100:330-335. https://doi.org/10.1073/pnas.222681699

6. Braak H, Braak E (1991) Neuropathological stageing of Alzheimer-related changes. Acta Neuropathol 82:239-259. https://doi.org/10.1007/BF003 08809

7. Burnouf S, Gorsky MK, Dols J, Gronke S, Partridge L (2015) Abeta43 is neurotoxic and primes aggregation of Abeta40 in vivo. Acta Neuropathol 130:35-47. https://doi.org/10.1007/s00401-015-1419-y

8. Callahan MJ, Lipinski WJ, Bian F, Durham RA, Pack A, Walker LC (2001) Augmented senile plaque load in aged female beta-amyloid precursor protein-transgenic mice. Am J Pathol 158:1173-1177. https://doi.org/10. 1016/s0002-9440(10)64064-3

9. Charidimou A, Boulouis G, Gurol ME, Ayata C, Bacskai BJ, Frosch MP, Viswanathan A, Greenberg SM (2017) Emerging concepts in sporadic cerebral amyloid angiopathy. Brain 140:1829-1850. https://doi.org/10. 1093/brain/awx047

10. Chemuru S, Kodali R, Wetzel R (2016) C-terminal threonine reduces Abeta43 amyloidogenicity compared with Abeta42. J Mol Biol 428:274291. https://doi.org/10.1016/j.jmb.2015.06.008

11. Chishti MA, Yang DS, Janus C, Phinney AL, Horne P, Pearson J, Strome R, Zuker N, Loukides J, French J et al (2001) Early-onset amyloid deposition and cognitive deficits in transgenic mice expressing a double mutant form of amyloid precursor protein 695. J Biol Chem 276:21562-21570. https://doi.org/10.1074/jbc.M100710200

12. Citron M, Westaway D, Xia W, Carlson G, Diehl T, Levesque G, JohnsonWood K, Lee M, Seubert P, Davis A et al (1997) Mutant presenilins of
Alzheimer's disease increase production of 42-residue amyloid betaprotein in both transfected cells and transgenic mice. Nat Med 3:67-72. https://doi.org/10.1038/nm0197-67

13. Condello C, Lemmin T, Stöhr J, Nick M, Wu Y, Maxwell AM, Watts JC, Caro CD, Oehler A, Keene CD et al (2018) Structural heterogeneity and intersubject variability of Abeta in familial and sporadic Alzheimer's disease. Proc Natl Acad Sci U S A 115:E782-E791. https://doi.org/10.1073/pnas. 1714966115

14. Conicella AE, Fawzi NL (2014) The C-terminal threonine of Abeta43 nucleates toxic aggregation via structural and dynamical changes in monomers and protofibrils. Biochemistry 53:3095-3105. https://doi.org/ 10.1021/bi500131a

15. Di Fede G, Catania M, Maderna E, Ghidoni R, Benussi L, Tonoli E, Giaccone G, Moda F, Paterlini A, Campagnani I et al (2018) Molecular subtypes of Alzheimer's disease. Sci Rep 8:3269. https://doi.org/10.1038/ s41598-018-21641-1

16. Duff K, Eckman C, Zehr C, Yu X, Prada CM, Perez-tur J, Hutton M, Buee L, Harigaya Y, Yager D et al (1996) Increased amyloid-beta42(43) in brains of mice expressing mutant presenilin 1. Nature 383:710-713. https://doi. org/10.1038/383710a0

17. Duyckaerts C, Delatour B, Potier MC (2009) Classification and basic pathology of Alzheimer disease. Acta Neuropathol 118:5-36. https://doi. org/10.1007/s00401-009-0532-1

18. Duyckaerts C, Sazdovitch V, Ando K, Seilhean D, Privat N, Yilmaz Z, Peckeu L, Amar E, Comoy E, Maceski A et al (2018) Neuropathology of iatrogenic Creutzfeldt-Jakob disease and immunoassay of French cadaver-sourced growth hormone batches suggest possible transmission of tauopathy and long incubation periods for the transmission of Abeta pathology. Acta Neuropathol 135:201-212. https://doi.org/10.1007/ s00401-017-1791-x

19. Eisele YS, Obermuller U, Heilbronner G, Baumann F, Kaeser SA, Wolburg H, Walker LC, Staufenbiel M, Heikenwalder M, Jucker M (2010) Peripherally applied Abeta-containing inoculates induce cerebral beta-amyloidosis. Science 330:980-982. https://doi.org/10.1126/science.1194516

20. Fritschi SK, Langer F, Kaeser SA, Maia LF, Portelius E, Pinotsi D, Kaminski CF, Winkler DT, Maetzler W, Keyvani K et al (2014) Highly potent soluble amyloid-beta seeds in human Alzheimer brain but not cerebrospinal fluid. Brain 137:2909-2915. https://doi.org/10.1093/brain/awu255

21. Frontzek K, Lutz MI, Aguzzi A, Kovacs GG, Budka H (2016) Amyloid-beta pathology and cerebral amyloid angiopathy are frequent in iatrogenic Creutzfeldt-Jakob disease after dural grafting. Swiss Med Wkly 146:w14287. https://doi.org/10.4414/smw.2016.14287

22. Guardia-Laguarta C, Pera M, Clarimon J, Molinuevo JL, Sanchez-Valle R, Llado A, Coma M, Gomez-Isla T, Blesa R, Ferrer I et al (2010) Clinical, neuropathologic, and biochemical profile of the amyloid precursor protein 1716F mutation. J Neuropathol Exp Neurol 69:53-59. https://doi.org/10. 1097/NEN.0b013e3181c6b84d

23. Hamaguchi T, Taniguchi Y, Sakai K, Kitamoto T, Takao M, Murayama S, Iwasaki Y, Yoshida M, Shimizu H, Kakita A et al (2016) Significant association of cadaveric dura mater grafting with subpial Abeta deposition and meningeal amyloid angiopathy. Acta Neuropathol 132:313-315. https:// doi.org/10.1007/s00401-016-1588-3

24. Heilbronner G, Eisele YS, Langer F, Kaeser SA, Novotny R, Nagarathinam A, Aslund A, Hammarstrom P, Nilsson KP, Jucker M (2013) Seeded strain-like transmission of beta-amyloid morphotypes in APP transgenic mice. EMBO Rep 14:1017-1022. https://doi.org/10.1038/embor.2013.137

25. Herve D, Porche M, Cabrejo L, Guidoux C, Tournier-Lasserve E, Nicolas G, Adle-Biassette H, Plu I, Chabriat H, Duyckaerts C (2018) Fatal Abeta cerebral amyloid angiopathy 4 decades after a dural graft at the age of 2 years. Acta Neuropathol. https://doi.org/10.1007/s00401-018-1828-9

26. Hirayama A, Horikoshi Y, Maeda M, Ito M, Takashima S (2003) Characteristic developmental expression of amyloid beta40, 42 and 43 in patients with down syndrome. Brain Dev 25:180-185. https://doi.org/10.1016/ s0387-7604(02)00209-7

27. lizuka T, Shoji M, Harigaya Y, Kawarabayashi T, Watanabe M, Kanai M, Hirai S (1995) Amyloid beta-protein ending at Thr43 is a minor component of some diffuse plaques in the Alzheimer's disease brain, but is not found in cerebrovascular amyloid. Brain Res 702:275-278. https://doi.org/10.1016/ 0006-8993(95)01163-2 
28. Jakel L, Boche D, Nicoll JAR, Verbeek MM (2019) Abeta43 in human Alzheimer's disease: effects of active Abeta42 immunization. Acta Neuropathol Commun 7:141. https://doi.org/10.1186/s40478-019-0791-6

29. Jarrett JT, Berger EP, Lansbury PT Jr (1993) The carboxy terminus of the beta amyloid protein is critical for the seeding of amyloid formation: implications for the pathogenesis of Alzheimer's disease. Biochemistry 32:4693-4697. https://doi.org/10.1021/bi00069a001

30. Jaunmuktane Z, Mead S, Ellis M, Wadsworth JD, Nicoll AJ, Kenny J, Launchbury F, Linehan J, Richard-Loendt A, Walker AS et al (2015) Evidence for human transmission of amyloid-beta pathology and cerebral amyloid angiopathy. Nature 525:247-250. https://doi.org/10.1038/natur e15369

31. Jucker M, Walker LC (2013) Self-propagation of pathogenic protein aggregates in neurodegenerative diseases. Nature 501:45-51. https://doi.org/ 10.1038/nature12481

32. Kane MD, Lipinski WJ, Callahan MJ, Bian F, Durham RA, Schwarz RD, Roher AE, Walker LC (2000) Evidence for seeding of beta -amyloid by intracerebral infusion of Alzheimer brain extracts in beta -amyloid precursor protein-transgenic mice. J Neurosci 20:3606-3611

33. Katzmarski N, Ziegler-Waldkirch S, Scheffler N, Witt C, Abou-Ajram C, Nuscher B, Prinz M, Haass C, Meyer-Luehmann M (2020) Abeta oligomers trigger and accelerate Abeta seeding. Brain Pathol 30:36-45. https://doi. org/10.1111/bpa.12734

34. Keller L, Welander $\mathrm{H}$, Chiang HH, Tjernberg LO, Nennesmo I, Wallin AK, Graff C (2010) The PSEN1 I143T mutation in a Swedish family with Alzheimer's disease: clinical report and quantification of Abeta in different brain regions. Eur J Hum Genet 18:1202-1208. https://doi.org/10.1038/ejhg. 2010.107

35. Kim T, Vidal GS, Djurisic M, William CM, Birnbaum ME, Garcia KC, Hyman BT, Shatz CJ (2013) Human LilrB2 is a beta-amyloid receptor and its murine homolog PirB regulates synaptic plasticity in an Alzheimer's model. Science 341:1399-1404. https://doi.org/10.1126/science.1242077

36. Klingstedt T, Aslund A, Simon RA, Johansson LB, Mason JJ, Nystrom S, Hammarstrom P, Nilsson KP (2011) Synthesis of a library of oligothiophenes and their utilization as fluorescent ligands for spectral assignment of protein aggregates. Org Biomol Chem 9:8356-8370. https://doi. org/10.1039/c1ob05637a

37. Kodali R, Williams AD, Chemuru S, Wetzel R (2010) Abeta(1-40) forms five distinct amyloid structures whose beta-sheet contents and fibril stabilities are correlated. J Mol Biol 401:503-517. https://doi.org/10.1016/j.jmb. 2010.06.023

38. Kollmer M, Close W, Funk L, Rasmussen J, Bsoul A, Schierhorn A, Schmidt M, Sigurdson CJ, Jucker M, Fandrich M (2019) Cryo-EM structure and polymorphism of Abeta amyloid fibrils purified from Alzheimer's brain tissue. Nat Commun 10:4760. https://doi.org/10.1038/s41467-019-12683-8

39. Kovacs GG, Lutz MI, Ricken G, Strobel T, Hoftberger R, Preusser M, Regelsberger G, Honigschnabl S, Reiner A, Fischer P et al (2016) Dura mater is a potential source of Abeta seeds. Acta Neuropathol 131:911-923. https:// doi.org/10.1007/s00401-016-1565-x

40. Kretner B, Trambauer J, Fukumori A, Mielke J, Kuhn PH, Kremmer E, Giese A, Lichtenthaler SF, Haass C, Arzberger T et al (2016) Generation and deposition of Abeta43 by the virtually inactive presenilin- 1 L435F mutant contradicts the presenilin loss-of-function hypothesis of Alzheimer's disease. EMBO Mol Med 8:458-465. https://doi.org/10.15252/emmm.20150 5952

41. Kummer MP, Heneka MT (2014) Truncated and modified amyloid-beta species. Alzheimer's Res Ther 6:28. https://doi.org/10.1186/alzrt258

42. Lambert MP, Barlow AK, Chromy BA, Edwards C, Freed R, Liosatos M, Morgan TE, Rozovsky I, Trommer B, Viola KL et al (1998) Diffusible, nonfibrillar ligands derived from Abeta 1-42 are potent central nervous system neurotoxins. Proc Natl Acad Sci U S A 95:6448-6453. https://doi.org/10. 1073/pnas.95.11.6448

43. Langer F, Eisele YS, Fritschi SK, Staufenbiel M, Walker LC, Jucker M (2011) Soluble Abeta seeds are potent inducers of cerebral beta-amyloid deposition. J Neurosci 31:14488-14495. https://doi.org/10.1523/JNEUROSCI. 3088-11.2011

44. Lau A, So RWL, Lau HHC, Sang JC, Ruiz-Riquelme A, Fleck SC, Stuart E, Menon S, Visanji NP, Meisl G et al (2020) alpha-Synuclein strains target distinct brain regions and cell types. Nat Neurosci 23:21-31. https://doi. org/10.1038/s41593-019-0541-x
45. Lau HHC, Ingelsson M, Watts JC (2020) The existence of Abeta strains and their potential for driving phenotypic heterogeneity in Alzheimer's disease. Acta Neuropathol. https://doi.org/10.1007/s00401-020-02201-2

46. Lau HHC, Lau A, Watts JC (2018) Discriminating strains of self-propagating protein aggregates using a conformational stability assay. Methods Mol Biol 1777:339-354. https://doi.org/10.1007/978-1-4939-7811-3_22

47. Lauren J, Gimbel DA, Nygaard HB, Gilbert JW, Strittmatter SM (2009) Cellular prion protein mediates impairment of synaptic plasticity by amyloid-beta oligomers. Nature 457:1128-1132. https://doi.org/10.1038/ nature07761

48. Lauridsen C, Sando SB, Moller I, Berge G, Pomary PK, Grontvedt GR, Salvesen O, Brathen G, White LR (2017) Cerebrospinal fluid abeta43 is reduced in early-onset compared to late-onset Alzheimer's disease, but has similar diagnostic accuracy to Abeta42. Front Aging Neurosci 9:210. https://doi.org/10.3389/fnagi.2017.00210

49. Lauwers E, Lalli G, Brandner S, Collinge J, Compernolle V, Duyckaerts C, Edgren G, Haik S, Hardy J, Helmy A et al (2020) Potential human transmission of amyloid beta pathology: surveillance and risks. Lancet Neurol 19:872-878. https://doi.org/10.1016/S1474-4422(20)30238-6

50. Legname G, Nguyen HO, Peretz D, Cohen FE, DeArmond SJ, Prusiner SB (2006) Continuum of prion protein structures enciphers a multitude of prion isolate-specified phenotypes. Proc Natl Acad Sci U S A 103:1910519110. https://doi.org/10.1073/pnas.0608970103

51. Lichtenthaler SF, Wang R, Grimm H, Uljon SN, Masters CL, Beyreuther K (1999) Mechanism of the cleavage specificity of Alzheimer's disease gamma-secretase identified by phenylalanine-scanning mutagenesis of the transmembrane domain of the amyloid precursor protein. Proc Natl Acad Sci U S A 96:3053-3058. https://doi.org/10.1073/pnas.96.6.3053

52. Lu JX, Qiang W, Yau WM, Schwieters CD, Meredith SC, Tycko R (2013) Molecular structure of beta-amyloid fibrils in Alzheimer's disease brain tissue. Cell 154:1257-1268. https://doi.org/10.1016/j.cell.2013.08.035

53. Meinhardt J, Sachse C, Hortschansky P, Grigorieff N, Fandrich M (2009) Abeta(1-40) fibril polymorphism implies diverse interaction patterns in amyloid fibrils. J Mol Biol 386:869-877. https://doi.org/10.1016/j.jmb. 2008.11.005

54. Meng P, Yoshida H, Tanji K, Matsumiya T, Xing F, Hayakari R, Wang L, Tsuruga K, Tanaka H, Mimura J et al (2015) Carnosic acid attenuates apoptosis induced by amyloid-beta 1-42 or 1-43 in SH-SY5Y human neuroblastoma cells. Neurosci Res 94:1-9. https://doi.org/10.1016/j. neures.2014.12.003

55. Meyer-Luehmann M, Coomaraswamy J, Bolmont T, Kaeser S, Schaefer C, Kilger E, Neuenschwander A, Abramowski D, Frey P, Jaton AL et al (2006) Exogenous induction of cerebral beta-amyloidogenesis is governed by agent and host. Science 313:1781-1784. https://doi.org/10.1126/science. 1131864

56. Morales R, Bravo-Alegria J, Duran-Aniotz C, Soto C (2015) Titration of biologically active amyloid-beta seeds in a transgenic mouse model of Alzheimer's disease. Sci Rep 5:9349. https://doi.org/10.1038/srep09349

57. Morales R, Duran-Aniotz C, Castilla J, Estrada LD, Soto C (2012) De novo induction of amyloid- $\beta$ deposition in vivo. Mol Psychiatry. https://doi.org/ $10.1038 / \mathrm{mp} .2011 .120$

58. Moro ML, Giaccone G, Lombardi R, Indaco A, Uggetti A, Morbin M, Saccucci S, Di Fede G, Catania M, Walsh DM et al (2012) APP mutations in the Abeta coding region are associated with abundant cerebral deposition of Abeta38. Acta Neuropathol 124:809-821. https://doi.org/10.1007/ s00401-012-1061-x

59. Nakaya $Y$, Yamane T, Shiraishi H, Wang HQ, Matsubara E, Sato T, Dolios G, Wang R, De Strooper B, Shoji M et al (2005) Random mutagenesis of presenilin-1 identifies novel mutants exclusively generating long amyloid beta-peptides. J Biol Chem 280:19070-19077. https://doi.org/10.1074/ jbc.M501130200

60. Nussbaum JM, Schilling S, Cynis H, Silva A, Swanson E, Wangsanut T, Tayler K, Wiltgen B, Hatami A, Ronicke R et al (2012) Prion-like behaviour and tau-dependent cytotoxicity of pyroglutamylated amyloid-beta. Nature 485:651-655. https://doi.org/10.1038/nature11060

61. Nystrom S, Psonka-Antonczyk KM, Ellingsen PG, Johansson LB, Reitan N Handrick S, Prokop S, Heppner FL, Wegenast-Braun BM, Jucker M et al (2013) Evidence for age-dependent in vivo conformational rearrangement within Abeta amyloid deposits. ACS Chem Biol 8:1128-1133. https://doi.org/10.1021/cb4000376 
62. Oakley DH, Chung M, Klickstein N, Commins C, Hyman BT, Frosch MP (2020) The Alzheimer disease-causing presenilin-1 L435F mutation causes increased production of soluble Abeta43 species in patientderived iPSC-neurons, closely mimicking matched patient brain tissue. J Neuropathol Exp Neurol 79:592-604. https://doi.org/10.1093/jnen/nlaa0 25

63. Paravastu AK, Leapman RD, Yau WM, Tycko R (2008) Molecular structural basis for polymorphism in Alzheimer's beta-amyloid fibrils. Proc Natl Acad Sci U S A 105:18349-18354. https://doi.org/10.1073/pnas.0806270105

64. Paravastu AK, Qahwash I, Leapman RD, Meredith SC, Tycko R (2009) Seeded growth of beta-amyloid fibrils from Alzheimer's brain-derived fibrils produces a distinct fibril structure. Proc Natl Acad Sci U S A 106:7443-7448. https://doi.org/10.1073/pnas.0812033106

65. Parvathy S, Davies P, Haroutunian V, Purohit DP, Davis KL, Mohs RC, Park H, Moran TM, Chan JY, Buxbaum JD (2001) Correlation between Abetax-40-, Abetax-42-, and Abetax-43-containing amyloid plaques and cognitive decline. Arch Neurol 58:2025-2032. https://doi.org/10.1001/archneur.58.12. 2025

66. Petkova AT, Leapman RD, Guo Z, Yau WM, Mattson MP, Tycko R (2005) Selfpropagating, molecular-level polymorphism in Alzheimer's beta-amyloid fibrils. Science 307:262-265. https://doi.org/10.1126/science.1105850

67. Prusiner SB (2012) Cell biology. A unifying role for prions in neurodegenerative diseases. Science 336:1511-1513. https://doi.org/10.1126/science.12229 51

68. Purro SA, Farrow MA, Linehan J, Nazari T, Thomas DX, Chen Z, Mengel D, Saito T, Saido T, Rudge P et al (2018) Transmission of amyloid-beta protein pathology from cadaveric pituitary growth hormone. Nature 564:415-419. https://doi.org/10.1038/s41586-018-0790-y

69. Qiang W, Yau WM, Lu JX, Collinge J, Tycko R (2017) Structural variation in amyloid-beta fibrils from Alzheimer's disease clinical subtypes. Nature 541:217-221. https://doi.org/10.1038/nature20814

70. Rasmussen J, Mahler J, Beschorner N, Kaeser SA, Hasler LM, Baumann F, Nystrom S, Portelius E, Blennow K, Lashley T et al (2017) Amyloid polymorphisms constitute distinct clouds of conformational variants in different etiological subtypes of Alzheimer's disease. Proc Natl Acad Sci U S A 114:13018-13023. https://doi.org/10.1073/pnas.1713215114

71. Ridley RM, Baker HF, Windle CP, Cummings RM (2006) Very long term studies of the seeding of beta-amyloidosis in primates. J Neural Transm 113:12431251. https://doi.org/10.1007/s00702-005-0385-2

72. Ritchie DL, Adlard P, Peden AH, Lowrie S, Le Grice M, Burns K, Jackson RJ, Yull H, Keogh MJ, Wei W et al (2017) Amyloid-beta accumulation in the CNS in human growth hormone recipients in the UK. Acta Neuropathol 134:221-240. https://doi.org/10.1007/s00401-017-1703-0

73. Ruiz-Riquelme A, Lau HHC, Stuart E, Goczi AN, Wang Z, Schmitt-Ulms G, Watts JC (2018) Prion-like propagation of beta-amyloid aggregates in the absence of APP overexpression. Acta Neuropathol Commun 6:26. https:// doi.org/10.1186/s40478-018-0529-x

74. Saito T, Matsuba Y, Mihira N, Takano J, Nilsson P, Itohara S, I wata N, Saido TC (2014) Single App knock-in mouse models of Alzheimer's disease. Nat Neurosci 17:661-663. https://doi.org/10.1038/nn.3697

75. Saito T, Matsuba Y, Yamazaki N, Hashimoto S, Saido TC (2016) Calpain activation in Alzheimer's model mice is an artifact of APP and presenilin overexpression. J Neurosci 36:9933-9936. https://doi.org/10.1523/JNEUR OSCl.1907-16.2016

76. Saito T, Suemoto T, Brouwers N, Sleegers K, Funamoto S, Mihira N, Matsuba Y, Yamada K, Nilsson P, Takano J et al (2011) Potent amyloidogenicity and pathogenicity of Abeta43. Nat Neurosci 14:1023-1032. https://doi.org/10. 1038/nn.2858

77. Sandebring A, Welander H, Winblad B, Graff C, Tjernberg LO (2013) The pathogenic abeta43 is enriched in familial and sporadic Alzheimer disease. PLoS ONE 8:e55847. https://doi.org/10.1371/journal.pone.0055847

78. Scheuner D, Eckman C, Jensen M, Song X, Citron M, Suzuki N, Bird TD, Hardy J, Hutton M, Kukull W et al (1996) Secreted amyloid beta-protein similar to that in the senile plaques of Alzheimer's disease is increased in vivo by the presenilin 1 and 2 and APP mutations linked to familial Alzheimer's disease. Nat Med 2:864-870. https://doi.org/10.1038/nm0896-864

79. Seither KM, McMahon HA, Singh N, Wang H, Cushman-Nick M, Montalvo GL, DeGrado WF, Shorter J (2014) Specific aromatic foldamers potently inhibit spontaneous and seeded Abeta42 and Abeta43 fibril assembly. Biochem J 464:85-98. https://doi.org/10.1042/BJ20131609
80. Selkoe DJ, Hardy J (2016) The amyloid hypothesis of Alzheimer's disease at 25 years. EMBO Mol Med 8:595-608. https://doi.org/10.15252/emmm.20160 6210

81. Sevigny J, Chiao P, Bussiere T, Weinreb PH, Williams L, Maier M, Dunstan R, Salloway S, Chen T, Ling Y et al (2016) The antibody aducanumab reduces Abeta plaques in Alzheimer's disease. Nature 537:50-56. https://doi.org/10. 1038/nature19323

82. Staufenbiel M, Paganetti PA (2000) Electrophoretic separation and immunoblotting of abeta(1-40) and abeta (1-42). Methods Mol Med 32:91-99. https://doi.org/10.1385/1-59259-195-7:91

83. Stöhr J, Condello C, Watts JC, Bloch L, Oehler A, Nick M, DeArmond SJ, Giles K, DeGrado WF, Prusiner SB (2014) Distinct synthetic Abeta prion strains producing different amyloid deposits in bigenic mice. Proc Natl Acad Sci U S A 111:10329-10334. https://doi.org/10.1073/pnas.1408968111

84. Stöhr J, Watts JC, Mensinger ZL, Oehler A, Grillo SK, DeArmond SJ, Prusiner SB, Giles K (2012) Purified and synthetic Alzheimer's amyloid beta (Abeta) prions. Proc Natl Acad Sci U S A 109:11025-11030. https://doi.org/10.1073/ pnas.1206555109

85. Sturchler-Pierrat C, Abramowski D, Duke M, Wiederhold KH, Mistl C, Rothacher S, Ledermann B, Burki K, Frey P, Paganetti PA et al (1997) Two amyloid precursor protein transgenic mouse models with Alzheimer disease-like pathology. Proc Natl Acad Sci USA 94:13287-13292

86. Takami M, Nagashima Y, Sano Y, Ishihara S, Morishima-Kawashima M, Funamoto S, Ihara Y (2009) gamma-Secretase: successive tripeptide and tetrapeptide release from the transmembrane domain of beta-carboxyl terminal fragment. J Neurosci 29:13042-13052. https://doi.org/10.1523/ JNEUROSCI.2362-09.2009

87. Tambini MD, D'Adamio L (2020) Knock-in rats with homozygous PSEN1 (L435F) Alzheimer mutation are viable and show selective gammasecretase activity loss causing low Abeta40/42 and high Abeta43. J Biol Chem 295:7442-7451. https://doi.org/10.1074/jbc.RA120.012542

88. Thal DR, Rub U, Orantes M, Braak H (2002) Phases of A beta-deposition in the human brain and its relevance for the development of AD. Neurology 58:1791-1800. https://doi.org/10.1212/wnl.58.12.1791

89. Trambauer J, Rodriguez Sarmiento RM, Fukumori A, Feederle R, Baumann K, Steiner H (2020) Abeta43-producing PS1 FAD mutants cause altered substrate interactions and respond to gamma-secretase modulation. EMBO Rep 21:e47996. https://doi.org/10.15252/embr.201947996

90. Uhlmann RE, Rother C, Rasmussen J, Schelle J, Bergmann C, Ullrich Gavilanes EM, Fritschi SK, Buehler A, Baumann F, Skodras A et al (2020) Acute targeting of pre-amyloid seeds in transgenic mice reduces Alzheimer-like pathology later in life. Nat Neurosci 23:1580-1588. https://doi.org/10.1038/ s41593-020-00737-w

91. Veugelen S, Saito T, Saido TC, Chavez-Gutierrez L, De Strooper B (2016) Familial Alzheimer's disease mutations in presenilin generate amyloidogenic abeta peptide seeds. Neuron 90:410-416. https://doi.org/10.1016/j.neuron. 2016.03.010

92. Walker LC (2020) Abeta plaques. Free Neuropathol 1:31. https://doi.org/10. 17879/freeneuropathology-2020-3025

93. Walker LC, Callahan MJ, Bian F, Durham RA, Roher AE, Lipinski WJ (2002) Exogenous induction of cerebral beta-amyloidosis in betaAPP-transgenic mice. Peptides 23:1241-1247. https://doi.org/10.1016/s0196-9781(02) 00059-1

94. Watts JC, Condello C, Stöhr J, Oehler A, Lee J, DeArmond SJ, Lannfelt L, Ingelsson M, Giles K, Prusiner SB (2014) Serial propagation of distinct strains of Abeta prions from Alzheimer's disease patients. Proc Natl Acad Sci U S A 111:10323-10328. https://doi.org/10.1073/pnas.1408900111

95. Watts JC, Giles K, Grillo SK, Lemus A, DeArmond SJ, Prusiner SB (2011) Bioluminescence imaging of Abeta deposition in bigenic mouse models of Alzheimer's disease. Proc Natl Acad Sci U S A 108:2528-2533. https://doi. org/10.1073/pnas.1019034108

96. Welander H, Franberg J, Graff C, Sundstrom E, Winblad B, Tjernberg LO (2009) Abeta43 is more frequent than Abeta40 in amyloid plaque cores from Alzheimer disease brains. J Neurochem 110:697-706. https://doi.org/ 10.1111/j.1471-4159.2009.06170.x

97. Ye L, Rasmussen J, Kaeser SA, Marzesco AM, Obermuller U, Mahler J, Schelle J, Odenthal J, Kruger C, Fritschi SK et al (2017) Abeta seeding potency peaks in the early stages of cerebral beta-amyloidosis. EMBO Rep 18:1536-1544. https://doi.org/10.15252/embr.201744067 
98. Zou K, Liu J, Watanabe A, Hiraga S, Liu S, Tanabe C, Maeda T, Terayama Y, Takahashi S, Michikawa M et al (2013) Abeta43 is the earliest-depositing Abeta species in APP transgenic mouse brain and is converted to Abeta41 by two active domains of ACE. Am J Pathol 182:2322-2331. https://doi.org/ 10.1016/j.ajpath.2013.01.053

\section{Publisher's Note}

Springer Nature remains neutral with regard to jurisdictional claims in published maps and institutional affiliations.
Ready to submit your research? Choose BMC and benefit from:

- fast, convenient online submission

- thorough peer review by experienced researchers in your field

- rapid publication on acceptance

- support for research data, including large and complex data types

- gold Open Access which fosters wider collaboration and increased citations

- maximum visibility for your research: over 100M website views per year

At BMC, research is always in progress.

Learn more biomedcentral.com/submissions 